\title{
Lewis Acid-Catalyzed Reactions of Anthrone: Preference for Cycloaddition Reaction over Conjugate Addition Depending on the Functionality of $\alpha, \beta$-Unsaturated Carbonyl Compounds
}

\author{
Woonphil Baik, ${ }^{*}$ Cheol Hoon Yoon, Sangho Koo, Hakwon Kim, ${ }_{\uparrow}{ }^{, \star}$ Jihan Kim, ${ }^{\dagger}$ Jeongryul Kim, ${ }^{\dagger}$ and Soodong Hong ${ }^{\dagger}$ \\ Department of Chemistry; Myong Ji Universitw, Yong In, Kyting Ki Do 449-728. Korea \\ "Department of Chemistry and GNRl, Kyung Hee University, Stuwon 419-701, Korea \\ Received Janiary 9,2004
}

\begin{abstract}
The Lewis acid-catalyzed reaclions of anthrone with a variety of ethylenic substrates under various conditions have been studied. It has been observed that depending on kinds of ethylenic substrates and catalysts, products were varied. In particular, the $\mathrm{ZnCl}_{2}$-catalyzed reaction of anthrone with $\alpha, \beta$-unsalurated ester gave bridged compounds 3 (Diels-Alder adduct type) and mono-Michacl adduct 4 exclusively, while the base-catalyzed reaction gave 10,10-bis-Michacl adduct as a major product independent of the amount of ethylenic substrate and base. Bridged compounds 3 were easily converted to the corresponding mono-Michacl adduct $\mathbf{4}$ by a catalytic amount of base. Further Michael reaction of mono-Michacl adducts with different ethylenic substrates in the presence of a calalytic amount of alkoxide gave unsymmetrical 10,10-bis Michael adducts in good or moderate yiclds.
\end{abstract}

Key Words : Anthrone, Lewis acid. Cycloaddition, Conjugated addition, Michael reaction

Anthrone 1 and anthracenol 2 are typical examples of keto-enol isomerization in solution (eq. 1).' Anthracenolate ion generated from the deprotonation of anthrone by base leads to a consecutive double Michael reaction ${ }^{2}$ which is often observed with substrates containing active methylene groups, such as indanone, fluorene, or acetophenone. ${ }^{3}$ In addition to the Michael reaction of anthrone. Diels-Alder reactions of anthracenol 2 have been investigated in conjunction with 9-substituted anthracenes. ${ }^{4}$<smiles>O=C1c2ccccc2Cc2ccccc21</smiles>

1

$\Uparrow K_{\text {eq }}$<smiles>Oc1c2ccccc2cc2ccccc12</smiles>

2
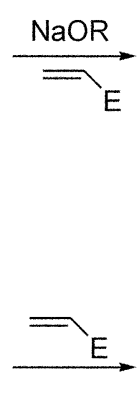
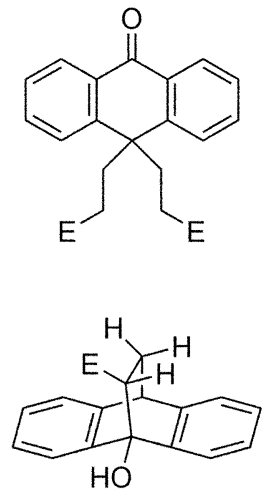

Anthracene has been shown to have only modest activity as a diene (HOMO energy, $-8.12 \mathrm{eV}$ ). On the other hand, 9alkoxy-substituted anthracenes ( $-\mathrm{O}$-alkylated anthrone) and anthracenol, which have higher HOMO energies ( -8.07 and $-7.90 \mathrm{eV}$, respectively), can act as better dienes toward $\alpha, \beta$ unsaturated carbonyl compounds in the classical Diels-Alder cycloaddition (the main MO interaction between HOMO of a diene and LUMO of a dienophile). ${ }^{5}$ Since the equilibrium constant between the tautomers anthrone and anthracenol is known to be strongly solvent-dependent $\left(K_{\text {cef }}-0 . \mathrm{l}\right.$ in $\mathrm{MeOH}$, $10^{-3}$ in $\mathrm{CHCl}_{3}$, and 1.5 in DMSO), ${ }^{1}$ the successful addition of dienophile to anthrone to give a Diels-Alder adduct has been limited. Reported attempts have involved the treatment of anthrone with a highly reactive dienophile, such as dimethyl acetylenedicarboxylate or maleic anhydride in boiling acetic acid. $\mathrm{On}$ the other hand, anthracenolate ion also acts as a highly reactive 1 -oxido diene. ${ }^{7}$ and has been shown to exhibit high diene reactivity in Diels-Alder reactions. For example. Meeks ef al. reported that anthracenolate ion is condensed with a poor dienophile, ethylene, to give a DielsAlder adduct at high pressure and high temperature, but they did not report any other dienophiles. ${ }^{2: t}$ Recently, Rickborn demonstrated that the treatment of anthrone with a weak base gives 1 -oxido diene (= anthracenolate ion), leading to a Diels-Alder reaction with highly reactive dienophiles in aprotic solvent, ${ }^{8}$ while, anthracenolate ion leads to a 1.4conjugate addition reaction with $\alpha, \beta$-unsaturated carbonyl compounds in protic solvents. ${ }^{2 \pi .8}$ Thus, even though anthracenolate ion is highly capable of acting as a diene in the Diels-Alder reaction, changing the base, solvent, or dienophile can result in either cycloadduct or Michael adduct. An anthracenolate ion can also undergo the $\mathrm{O}$ - or C-alkylation. analogous to a phenoxide ion. ${ }^{9}$ Previous investigations led us to consider the possibility of cycloaddition reactions of anthrone with $\alpha \beta$-unsaturated carbonyl compounds, since the equilibrium position between the two tautomers favors anthracenol in acidic conditions, which is capable of leading to the Diels-Alder adduct. Thus, a simple $\alpha, \beta$-unsaturated ester, methyl acrylate, was used as a model compound, since it has a moderately low activity as a dienophile. ${ }^{10}$

The condensation of methyl acrylate with anthrone was tried in the presence of a catalytic amount of the Lewis acid $\mathrm{ZnCl}_{2}$ in ethanol, and cycloadduct $\mathbf{3 a}$ was formed as a major product; two Michael adducts $\mathbf{4 a}$ and $\mathbf{5 a}$ were also observed in small amounts (Scheme I). 
<smiles>CCOc1c2ccccc2cc2ccccc12</smiles>

7

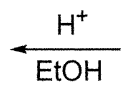<smiles>[R]C([R])C(O)(c1ccccc1)c1ccccc1C([R])(F)C([R])([R])F</smiles>

3<smiles>O=C1c2ccccc2Cc2ccccc21</smiles>

1<smiles>[R2]C=C([R])F</smiles><smiles>[R]C(F)C([R])C1(C([R])C([R])F)c2ccccc2C(=O)c2ccccc21</smiles>

a. $E=\mathrm{CO}_{2} \mathrm{Me}, \mathrm{R}_{1}=\mathrm{R}_{2}=\mathrm{H}, \mathrm{b} . \mathrm{E}=\mathrm{COCH}_{3}, \mathrm{R}_{1}=\mathrm{R}_{2}=\mathrm{H}, \mathrm{c} . \mathrm{E}=\mathrm{COPh}, \mathrm{R}_{1}=\mathrm{R}_{2}=\mathrm{H}$ :

d. $E=C N, R_{1}=R_{2}=H$, e. $E=S O_{2} P h . R_{1}=R_{2}=H$, f. $E=C_{2} E t, R_{1}=R_{2}=H$,

g. $E=\mathrm{CO}_{2} \mathrm{Bu}_{1}^{\mathrm{t}}, \mathrm{R}_{1}=\mathrm{R}_{2}=\mathrm{H}$, h. $\mathrm{E}, \mathrm{R}_{2}=\mathrm{CO}_{2} \mathrm{CH}_{2}, \mathrm{R}_{1}=\mathrm{H}$,

i. $\mathrm{E}=\mathrm{CO}_{2} \mathrm{Me}, \mathrm{R}_{1}=\mathrm{H}, \mathrm{R}_{2}=\mathrm{CO}_{2} \mathrm{Me}, \mathrm{j}$. $\mathrm{E}=\mathrm{CO}_{2} \mathrm{Et}, \mathrm{R}_{1}=\mathrm{H}, \mathrm{R}_{2}=\mathrm{CO}_{2} \mathrm{Et}$

Scheme 1. Reaction of anthrone with a variety of cthylenic substrates under various conditions.

Table 1. I entis acid-catalyzed reactions of anthrone with a variety of ethylenic substrates under various conditions

\begin{tabular}{|c|c|c|c|c|c|c|c|c|}
\hline \multirow{2}{*}{ liniry } & \multirow{2}{*}{ ethylenic substrate } & \multirow{2}{*}{$\begin{array}{l}\text { Lewis acid } \\
\text { (Equiv) }\end{array}$} & \multirow{2}{*}{ solvent } & \multirow{2}{*}{$\begin{array}{l}\operatorname{time} \\
\text { (h) }\end{array}$} & \multicolumn{4}{|c|}{ product. $\%$} \\
\hline & & & & & 3 & 4 & 5 & 7 \\
\hline I & methyl acrylate(a) & $7 n C 1_{2} .0 .1$ & I:101 I & 6 & 85 & 9 & 3 & 0 \\
\hline 2 & methyl acrylate(a) & $7 \mathrm{nC} \mathrm{I}_{2}, 0.01$ & $\mathrm{I}: 10 \mathrm{II}$ & 6 & 84 & 10 & 4 & 0 \\
\hline 3 & methyl acrylate(a) & $2 / \mathrm{nI}_{2} .0 .05$ & $1: 1011$ & 6 & 32 & 17 & 13 & 0 \\
\hline 4 & methyl acrylate(a) & $\mathrm{A} 1 \mathrm{CI} \mathrm{I}_{3,} 0.05$ & $1: 1011$ & 6 & 51 & 6 & 11 & 0 \\
\hline 5 & methyl acrylate(a) & $p-T S \wedge .0 .1$ & $1: 1011$ & 24 & 0 & 0 & 0 & 77 \\
\hline 6 & methy] acrylate(a) & $\mathrm{II}_{2} \mathrm{SO}_{4} 0.0 \mathrm{I}$ & $1: 1011$ & 10 & 0 & 0 & 0 & 81 \\
\hline 7 & melhyl vinyl ketone(b) & $7 \mathrm{nCl} \mathrm{I}_{2} 0.05$ & $1: 1011$ & 3 & 0 & 89 & 0 & 0 \\
\hline 8 & phensil vimyl kelone(c) & $\mathrm{YnC} \mathrm{I}_{2}, 0.05$ & MeOII & 2 & 0 & 47 & 0 & 0 \\
\hline 9 & acrilonitrile(d) & $7 \mathrm{nCl} \mathrm{Z}_{2} 0.05$ & IDMSO & 6 & 71 & 0 & 0 & 0 \\
\hline 10 & pheny] vinyl sullone(e) & $7 \mathrm{nCl}_{2}, 0.05$ & IDMSO & 24 & \multicolumn{4}{|c|}{ no reaction } \\
\hline
\end{tabular}

"Isolated y ield.

Table I summarizes the results for the reactions of anthrone with a variety of ethylenic substrates under various conditions. The products were not influenced by the amounts of Lewis acid or methyl acrylate (entries I and 2). By reducing the amount of $\mathrm{ZnCl} 2$ to as little as $0.01 \mathrm{~mol} \%$, the cycloaddition reaction also occurred to give a similar product ratio and yield. A comparison experiment was performed with other Lewis acids $\mathrm{AlCl}_{3}$ and $\mathrm{Znl}_{2}$ (entries 3 and 4). However, these other Lewis acids provided unsatisfactory results for the cycloaddition reaction. When mineral acid or $p$ toluenesulfonic acid ( $p$-]SA) was used instead of $\mathrm{ZnCl}_{2}$, acid-catalyzed ether formation of anthracenol preferentially occurred to give a single product, 9-ethoxyanthracene 7 (entries 5 and 6), which is formed when anthrone is refluxed in ethanol in the presence of $\mathrm{H}_{2} \mathrm{SO}_{4}$ without ethylenic substrate. $^{8 \mathrm{Ba}}$

It should be pointed out that anthrone in the presence of Lewis acid shows two distinctive characters, diene and Michael donor, depending on the functionality of the $\alpha . \beta$ unsaturated carbonyl compounds. Recently, we reported that 1,4-conjugated addition of anthrone with $\alpha . \beta$-unsaturated ketones proceeds to give mono-Michael adducts in the presence of $\mathrm{ZnCl}_{2}$, as shown in eq. 2 (entries 7 and 8)."<smiles>O=C1c2ccccc2Cc2ccccc21</smiles>

1

$(\mathrm{R}=\mathrm{Me}, \mathrm{Et}, \mathrm{Ph})$<smiles>O=C1c2ccccc2C(/C=C/P)c2ccccc21</smiles>

(2)

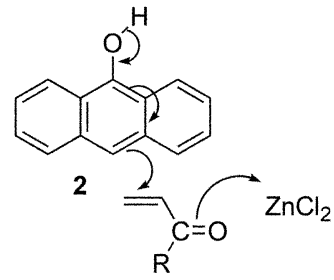

The success of the mono-Michael reaction with $\mathrm{ZnCl} 2$ 
Table 2. Lew is acid-eatalyzed reactions of anthrone with a varicty of $\alpha \beta$-unsaturated esters

\begin{tabular}{|c|c|c|c|c|c|c|c|}
\hline \multirow{2}{*}{ Entry } & \multirow{2}{*}{$\alpha, \beta$-unsaturated ssters } & \multirow{2}{*}{$\mathrm{ZnCl}_{2}$ (Equiv) } & \multirow{2}{*}{ solvents } & \multirow{2}{*}{ time (h) } & \multicolumn{3}{|c|}{ product. \%" } \\
\hline & & & & & 3 & 4 & 5 \\
\hline 1 & mathy] acrylate (a) & 0.1 & $\mathrm{EtOH}$ & 3 & 85 & 9 & 3 \\
\hline 2 & ethyl acrylate (f) & 0.01 & $\mathrm{EtOH}$ & 6 & 83 & 3 & 2 \\
\hline 3 & tert-butyl acrylate (g) & 0.05 & $\mathrm{EtOH}$ & 6 & 61 & 8 & 0 \\
\hline 4 & $2(5 / N)$-furanone $(\mathbf{h})$ & 0.01 & $\mathrm{EtOH}$ & 3 & 93 & 0 & 0 \\
\hline 5 & dimethyl fumarate (i) & 0.05 & DMSO & 4 & 90 & 0 & 0 \\
\hline 6 & diethyl fumarate $(\mathrm{j})$ & 0.05 & DMSO & 2 & 65 & 0 & 0 \\
\hline 7 & dimathy] malcate (i) & 0.05 & DMSO & 6 & 56 & 0 & 0 \\
\hline 8 & diethy] maleate (j) & 0.05 & DMSO & 24 & 20 & 0 & 0 \\
\hline
\end{tabular}

"Reaction temperature in EIOHI, reflux: in D.MSO, $80^{\circ} \mathrm{C}$. "Isolated yield.

may be explained by the equilibrium position between the tautomers, anthrone 1 and anthracenol 2, which lies towards the enol form in acidic media. Thus, the favorable anthracenol 2 reacts with methyl vinyl ketone to give the monoMichael adduct $\mathbf{4 b}$ under acidic conditions. In fact, the reactivities of methyl acrylate and methyl vinyl ketone as dienophiles are very similar (calculated I.UMO energies of -0.01 and $-0.07 \mathrm{eV}$, respectively). Meanwhile, the Michael reaction should be strongly influenced by the polarity of the $\mathrm{CC}$ double bond, and the electronic effects of the activating groups that produce polarity decrease in the order $\mathrm{CHO}>$ $\mathrm{COR}>\mathrm{CN}>\mathrm{CO}_{2} \mathrm{R}^{12}$ Methyl vinyl ketone, which has a highly polar double bond, is capable of acting as a Michael acceptor, and thus cycloaddition to give a Diels-Alder adduct 3b would be less favorable. While the Michael adduct is often converted to the cycloadduct when subjected to the same reaction conditions for a long period, the cycloadduct was not observed despite a prolonged reaction time of $24 \mathrm{~h}$. Meanwhile, methyl acrylate has moderate reactivity as a dienophile and a CC double bond with very low polarity. Therefore, it seems reasonable that the lewis acid-catalyzed reaction with methyl acrylate predominantly leads to the cycloaddition.

We examined the Lewis acid-catalyzed cycloaddition reactions with moderately to highly reactive ethylenic dienophiles, including $\alpha, \beta$-unsaturated nitrile, and sulfone (entries 9 and 10 ). These reactions were performed in DMSO using $\angle \mathrm{nCl}_{2}$ as the Lewis acid catalyst (typically 0.05 equiv). Reactions with acrylonitrile (entry 9) gave only Diels-Alder adduct 3d, and no trace of Michael adduct was observed. Negative results were observed with phenyl vinyl sulfone in that neither cycloadduct nor Michael adduct was produced. In fact, unsuccessful results have been reported in the Michael condensation of acetophenone with methyl vinyl sulfone." These results indicate that the relative activating effect of dienophiles decreases in the order nitrile $>$ ester $>$ sulfone, analogous to the case of Michael acceptor. In the present study, the success of $\mathrm{ZnCl}_{2}$-catalyzed cycloaddition reaction with alkyl acrylates was truly startling compared to other catalyzed processes such as the base-catalyzed DielsAlder reaction, which gives cycloadduct when alkyl acrylate is used as a solvent. ${ }^{8 \mathrm{~b}}$ It has been well documented that the rate of the Diels-Alder reaction is generally increased by a factor of $10^{5}$ with Lewis acid catalysis compared to other catalyzed themal processes. ${ }^{1.1}$

Fencouraged by our success with the cycloaddition with a mildly reactive dienophile, methyl acrylate, we next explored the analogous reaction with a variety of $\alpha_{n} \beta$-unsaturated esters. All of the $7 \mathrm{nCl}_{2}$-catalyzed cycloaddition were successful under similar conditions and provided the corresponding bridgehead alcohols in reasonable yields (Table 2).

In particular, only cycloadducts were obtained in reasonable yields with $\alpha$ - or $\beta$-substituted esters (entries 4-8). In attempt to examine the reaction pathway of cycloaddition with reactive ethylenic dienophiles under Lewis acid conditions, we studied the stereochemistry of cycloadducts with dialkyl fumarate and dialkyl maleate (entries 5-8). Dimethyl fumarate, which is $c a .10^{2}$ fold more reactive than methyl acrylate in other cycloaddition reactions, gave cycloadducts trans-3i in $90 \%$ yield (eq. 3).

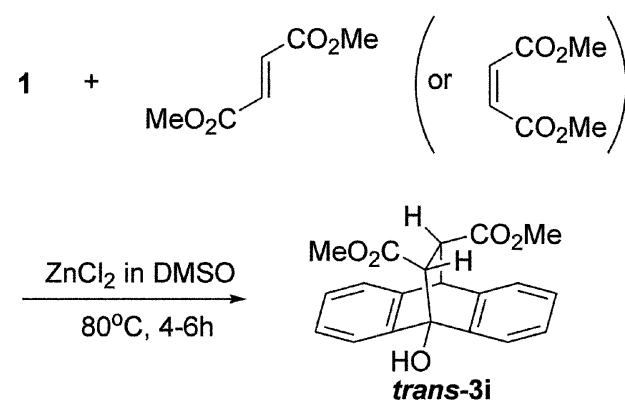

The stereochemistry of the dienophile was retained, based on the coupling constant in ${ }^{\mathrm{H}} \mathrm{H}-\mathrm{NMR}$. We also observed enhanced reactivity in DMSO, since the enol form 2 is favored by about a factor of 10 in DMSO compared to protic solvent.

The cis diester dimethyl maleate was also reacted with anthrone under the same conditions. Surprisingly, this cycloaddition was not stereospecific, and we observed a $100 \%$ inversion of dienophile geometry. To confirm the isomerization of dimethy] maleate to dimethyl fumarate under Lewis acid conditions, we performed a control experiment in the absence of anthrone. No isomerization was observed, even under more vigorous conditions by changing the solvent and the amount of $\mathrm{ZnCl}_{2}$. In fact. dimethyl maleate is less reactive in Diels-Alder reactions than 
dimethyl fumarate. Thus, a further stereochemistry study was performed with fumaronitrile and maleonitrile, since both are more reactive than dimethyl fumarate. ${ }^{10}$ The $7 . \mathrm{nCl}_{2}$ catalyzed cycloaddition reactions of anthrone with fumaronitrile and maleonitrile gave trans cycloadduct $\mathbf{8}$ and cis cycloadduct 9 in good yields, and with different stereochemical results than diesters (eq. 4).
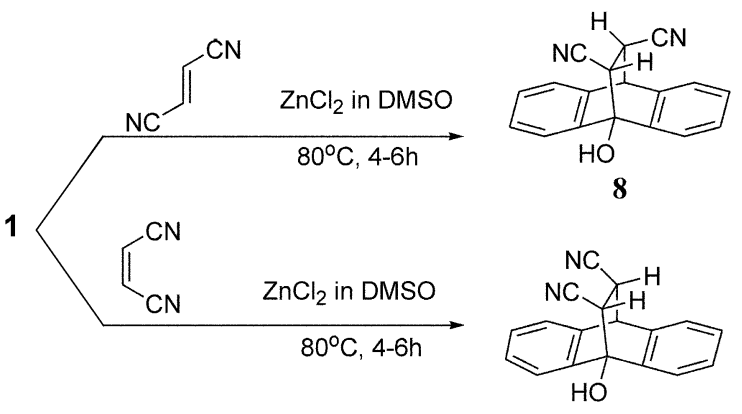

If we focus on the stereochemistry of cycloadducts in the $7 . \mathrm{nCl}_{2}$-catalyzed reactions with dimethyl maleate, it is worth noting that while the cycloaddition pathway may occur via stepwise cycloaddition mechanisms, the two-step (Michael + Aldol) can be excluded: (a) as mentioned previously, the product ratio of $\mathbf{3} /(\mathbf{4}+\mathbf{5})$ with methyl acrylate does not change during the reaction, and thus there is no evidence for the transformation of 4 to 3 , (b) even the Aldol condensation of the isolated mono-Michael adduct 4 in the presence of $7 . \mathrm{nCl}_{2}$ under the same conditions failed to give the cycloadduct (eq. 5), and (c) the base-catalyzed intramolecular Aldol condensation of $\mathbf{4}$ to 3 also failed, and instead 4 was isomerized to 9-substituted anthracenol 5 (eq. 5).

Another interesting result is observed when 3 is allowed to react with $\mathrm{NaOMe}$ in methanol at room temperature. Since the formation of the bridgehead alcohol 3 was promoted by $\mathrm{ZnCl}_{2 n}$ it was thought that the ring-opening reaction would<smiles>O=C1c2ccccc2C(CCF)c2ccccc21</smiles><smiles>CC(C)CCC(C)C</smiles><smiles>Oc1c2ccccc2c(CCF)c2ccccc12</smiles>

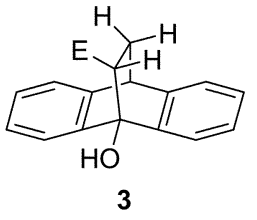

be facilitated by the loss of a proton to generate the monoMichael adduct 4, as shown in Scheme 2 (pathway a).

In fact, this reaction was time-dependent, an alicjuot taken at $30 \mathrm{~min}$ showed that the starting material had been consumed, to give exclusively 4 , Continued stirring for $3 \mathrm{~h}$ led to the exclusive formation of anthracenol 5. No other method has reported for the preparation of mono-Michael adduct $4\left(\mathrm{~F}:=\mathrm{CO}_{2} \mathrm{R}, \mathrm{CN}\right)$ and its tautomer 5 . The fragmentation of 3 to anthrone and methyl acrylate (pathway b) could not occur by way of an Fians accelerating effect of the oxido group, which is known as the oxido-accelerated retro Diels-Alder reaction. ${ }^{6.15}$ Thus, the formation of 4 could not be explained by the consecutive recombination of anthracenolate ion and methyl acrylate via the Michael process under basic conditions, since the consecutive double Michael reaction predominantly occurs very rapidly independent of the amount of base and methyl acrylate, as shown in Scheme 1. We also carried out cross experiments to contirm that the recombination of anthracenolate ion and methyl acrylate (pathway b) is not the reaction process. When $3\left(\mathrm{C}=\mathrm{CO}_{2} \mathrm{Me}\right)$ was treated with NaOMe in the presence of excess amounts of ethyl acrylate, it did not undergo Michael addition to give $4\left(\Gamma=\mathrm{CO}_{2} \mathrm{E} t\right)$, which cross-coupled with anthracenolate ion after the fragmentation sequence outlined in pathway $b$.
3

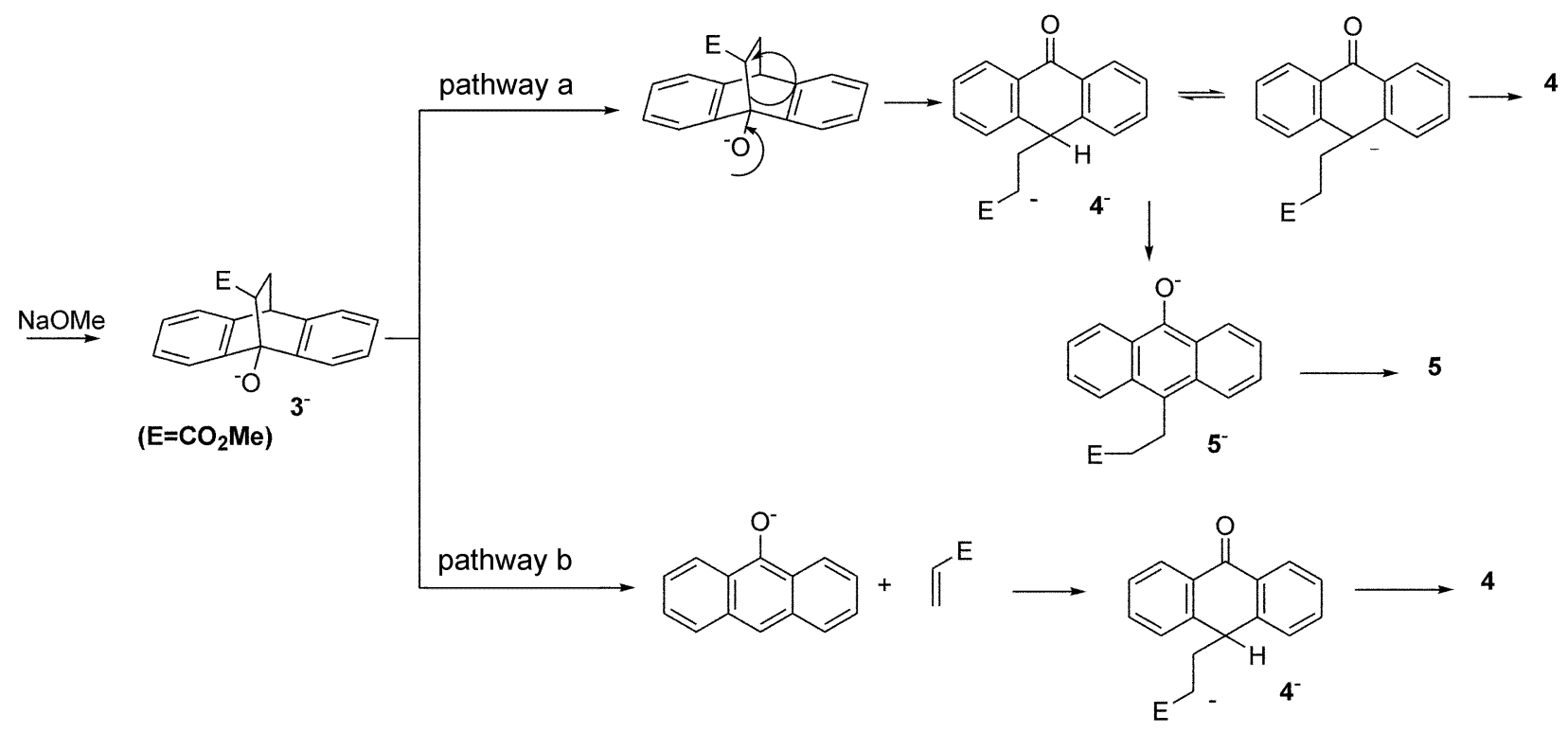

Scheme 2 
Thus, the retro Diels-Alder reaction for bridgehead alcohols 3 prepared from $\alpha, \beta$-unsaturated compounds would not be expected to occur via an oxido group generated from treatment with a base in alcohol, In fact, to accelerate the retro Diels-Alder reaction by an oxido substituent, we must consider the dramatic loss of basicity, i.e. the basicity of $\mathbf{3}^{-}$ and an anthracenolate ion at the oxygen atom, as a powerful driving force. ${ }^{\text {lsl }}$ The obvious resonance structures of anthracenolate ion suggest that the negative charge resides mainly on the ring carbon in protic solvents, since it acts as a Michael donor. Thus, the dramatic loss of basicity of $3^{-}$and of an anthracenolate ion would not to be expected to occur in protic solvents.

We next considered the consecutive reactions of monoMichael adducts $\mathbf{4}$ with different ethylenic substrates to synthesize the various unsymmetrical 10,10-disubstituted anthrones 11. The reaction of $4\left(\mathrm{E}^{\mathrm{l}}=\mathrm{CO}_{2} \mathrm{Me}, \mathrm{CO}_{2} \mathrm{\Gamma t}\right.$ and COMe) with ethylenic carbonyl compounds $\left(\Gamma^{2}=\mathrm{CO}_{2} \mathrm{Me}\right.$, $\mathrm{CO}_{2} \mathrm{Et}$ and COMe in case $A$ ) in the presence of LiHMDS in

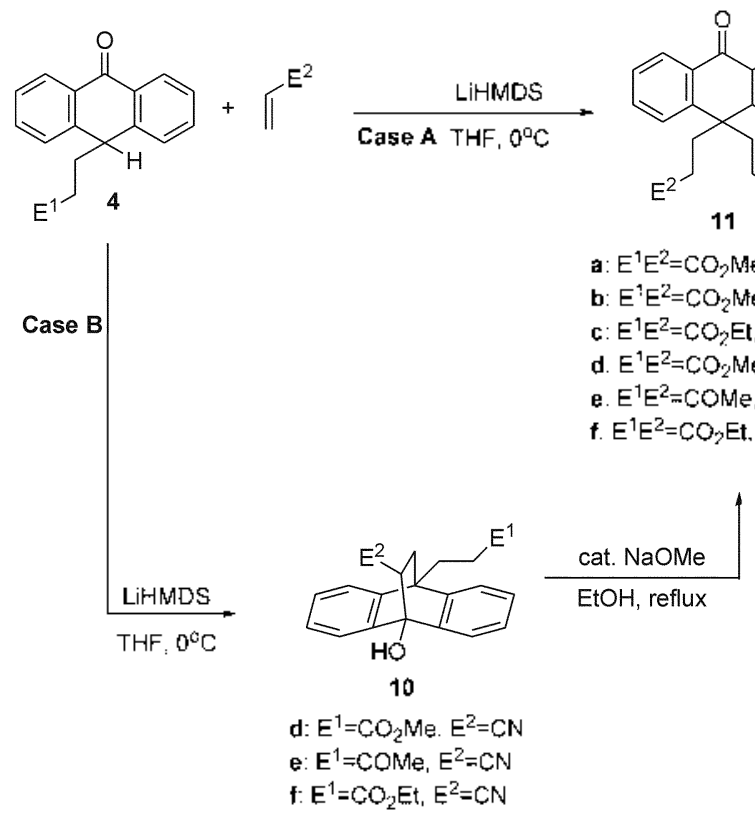

THF solvent gave the corresponding unsymmetrical 10,10disubstituted anthrones $11 \mathbf{a}, 11 \mathbf{b}, 11 \mathbf{c}$ (eq. 6). However, in case $\mathrm{B}$, the reaction of $\mathbf{4}\left(\mathrm{\Gamma}^{\prime}=\mathrm{CO}_{2} \mathrm{Me}, \mathrm{CO}_{2} \Gamma \mathrm{s}\right.$ and $\left.\mathrm{COMe}\right)$ with acrylonitrile $\left(\mathrm{F}^{2}=\mathrm{CN}\right)$ as an ethylenic substrate under the same reaction conditions gave cycloadduct 10 . The ringopening of the cycloadduct $\mathbf{1 0}$ to the corresponding unsymmetrical bis-Michael adduct 11 was also effected by treatment with a catalytic amount of $\mathrm{NaOMe}$ at room temperature.

A series of the cross-coupling reactions were performed in which either $\alpha \beta$-unsaturated ester, ketone or nitrile was allowed to react the cycloaddition reactions followed by the ring-openings (Table 3 ).

To compare the reactivities of anthrone under two distinctive conditions, we examined a series of $\alpha_{n} \beta$-unsaturated carbonyl, nitrile and sulfone compounds under basic conditions (eq. 7).

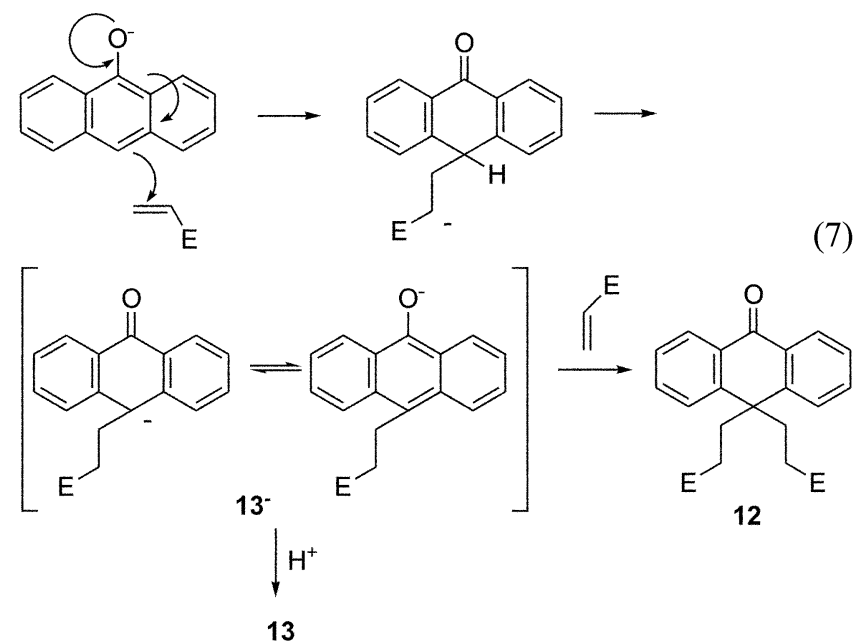

The results of these condensation reactions are summarized in Table 4. The base-catalyzed reactions of anthrone with ethylenic substrates gave the bis-Michael adduct 12 independent of the functional group by way of consecutive double 1,4-conjugated addition. We also found that the condensation reaction proceeded using both catalytic $(0.02$

Table 3. Formation of cross-coupled anthrones II via the consceutiwe cycloaddition and ring-opening reactions

\begin{tabular}{|c|c|c|c|c|c|c|c|c|}
\hline \multirow{2}{*}{ Entry } & \multirow{2}{*}{$\begin{array}{c}\text { Case } \\
\text { (equiv) }\end{array}$} & \multirow{2}{*}{$\begin{array}{c}4 \\
E^{1}\end{array}$} & \multirow{2}{*}{$\begin{array}{c}\mathrm{Cl}_{2}=\mathrm{CIIH}:^{2} \\
\mathrm{H}^{2}\end{array}$} & \multirow{2}{*}{$\begin{array}{l}\text { reaclion } \\
\text { lime }\end{array}$} & \multirow{2}{*}{$\begin{array}{l}10 \% \\
\text { Yield } \%\end{array}$} & \multicolumn{2}{|c|}{11} & \multirow{2}{*}{$\begin{array}{c}11^{6} \\
\text { sield } \%\end{array}$} \\
\hline & & & & & & $\bar{L}^{\prime}$ & $\mathrm{C}^{2}$ & \\
\hline 1 & $\mathrm{~A}$ & $\mathrm{CO}_{2} \mathrm{Mc}$ & COMc & $10 \mathrm{~h}$ & - & $\mathrm{CO}_{2} \mathrm{Mc}$ & COMe & 30 (a) \\
\hline 2 & $\mathrm{~A}$ & $\mathrm{CO}_{2} \mathrm{Mc}$ & $\mathrm{CO}_{2} \mathrm{Et}$ & $10 h$ & - & $\mathrm{CO}_{2} \mathrm{Mc}$ & $\mathrm{CO}_{2} \mathrm{Et}$ & 57 (b) \\
\hline 3 & A & $\mathrm{CO}_{2} \mathrm{Et}$ & COMe & $5 \mathrm{~h}$ & - & $\mathrm{CO}_{2} \mathrm{Et}$ & COMc & $44(c)$ \\
\hline 4 & $\mathrm{~A}$ & COMc & $\mathrm{CO}_{3} \mathrm{Mc}$ & $10 \mathrm{~h}$ & - & COML & $\mathrm{CO}_{2} \mathrm{Mc}$ & 45 (a) \\
\hline 5 & A & COMc & $\mathrm{CO}_{2} \mathrm{Et}$ & $6 h$ & - & COME & $\mathrm{CO}_{2} \mathrm{Et}$ & $41(c)$ \\
\hline 6 & B & $\mathrm{CO}_{2} \mathrm{Mc}$ & $\mathrm{CN}$ & $\begin{array}{l}3 h \\
4 h^{c}\end{array}$ & $85(\mathrm{~d})$ & $\mathrm{CO}_{2} \mathrm{Mc}$ & $\mathrm{CN}$ & $98(\mathbf{d})$ \\
\hline 7 & B & $\mathrm{COMc}$ & $\mathrm{CN}$ & $\begin{array}{c}2 \mathrm{~h} \\
20 \mathrm{~min}\end{array}$ & $72(\mathbf{e})$ & COME & $\mathrm{CN}$ & $98(e)$ \\
\hline 8 & B & $\mathrm{CO}_{2} \mathrm{Et}$ & $\mathrm{CN}$ & $\begin{array}{c}2 \mathrm{~h} \\
10 \mathrm{~h}\end{array}$ & $84(f)$ & $\mathrm{CO}_{2} \mathrm{Et}$ & $\mathrm{CN}$ & $82(f)$ \\
\hline
\end{tabular}

"Isolated yields alter recrystallization. "Isolated yields alter chromatographic purification. "First step (4 to 10) ssecond step (10 to 11$)$. 
equiv, and stoichiometric amounts of sodium alkoxide to produce the bis-Michael adducts $\mathbf{1 2}$ in similar yields. In particular, the consecutive double Michael reaction of anthrone with $\alpha, \beta$-unsaturated esters in the presence of base occurred to give only bis-Michael adducts $\mathbf{1} 2$ in fairly high yields (entries 1 and 2). The formation of bis-Michael adduct is independent of the amount of ester used. For example, 0.5 equiy of methyl acrylate was treated with 1.0 equiv of anthrone (1) in the presence of 0.1 equiv of $\mathrm{NaOMe}$ to give $21 \%$ of 12 and $78 \%$ of unreacted anthrone (1). None of the mono-Michael adduct 13a was formed. We followed the condensation reactions by GLC analysis and H-NMR, which showed no evidence for the formation of mono-Michael adduct. The decrease in anthrone is counterbalanced by the appearance of bis-Michael adduct, the concentration of which steadily increase until all of the anthrone was consumed.

The anthracenolate ion reacts with $\alpha, \beta$-unsaturated compounds and then undergoes a proton shift to give the more stable anthracenolate ion $13^{-}$. Presumably, $13^{-}$is more reactive towards ethylenic compounds than anthracenolate ion, and this reaction readily proceeds to give the bisMichael adduct 12, as shown in F.q. (7). We recently reported the sodium alkoxide-catalyzed consecutive double Michael reaction with a variety of $\alpha, \beta$-unsaturated ketones (entries 4-6). " In fact. limited examples of $\alpha, \beta$-unsaturated carbonyl compounds, such as methyl acrylate, methyl vinyl ketone and acrylonitrile, have been reported in the base-

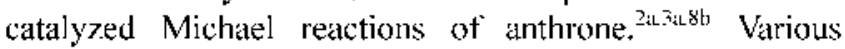
alkenes and other reaction conditions have not been reported at all. In contrast to the unsuccessful reaction of the anion of acetophenone with the mildly reactive Michael acceptor phenyl vinyl sulfone, ${ }^{1.3}$ the anthracenolate ion in ethanol gives the bis-Michael adduct $\mathbf{1 2} \mathbf{h}$ in high yield (entry 8 ). For $\alpha, \beta$-unsaturated compounds with $\alpha, \beta$-substituents (entries 9 to 12 ), no bis-Michael adducts were observed regardless of the amounts of substrates and $\mathrm{NaOCH}_{3}$, and only mono 10substituted anthrones (13i, 13j, 13k, 13l) were observed in reasonable yields.

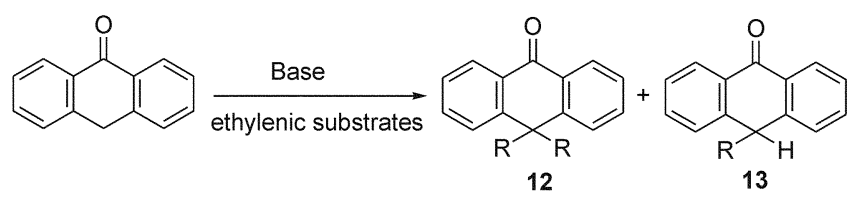

R a. $\mathrm{CH}_{2} \mathrm{CH}_{2} \mathrm{CO}_{2}$ Me. b. $\mathrm{CH}_{2} \mathrm{CH}_{2} \mathrm{CO}_{2}$ Ft. c. $\mathrm{CH}_{2} \mathrm{CH}_{2} \mathrm{CO}_{2}$ Ph. d. $\mathrm{CH}_{2} \mathrm{CH}\left(\mathrm{CH}_{3}\right) \mathrm{CO}_{2} \mathrm{HL}_{2}$ e. $\mathrm{CH}_{2} \mathrm{CH}_{2} \mathrm{C}(=\mathrm{O}) \mathrm{CH}_{3}$ f. $\mathrm{CH}_{2} \mathrm{CHI}_{2} \mathrm{C}(=\mathrm{O}) \mathrm{CH}_{2} \mathrm{ClI}_{2} \cdot \mathrm{g}$. $\mathrm{CH}_{2} \mathrm{CII}_{2} \mathrm{C}(=\mathrm{O}) \mathrm{Ph}$.

h. $\mathrm{CH}_{2} \mathrm{CH}_{2} \mathrm{CN}$. i. $\mathrm{CH}_{2} \mathrm{CH}_{2} \mathrm{SO}_{2} \mathrm{Ph}$. j. $\mathrm{CH}\left(\mathrm{CH}_{3}\right) \mathrm{CH}_{2} \mathrm{CO}_{2} \mathrm{Mc}$.

k. $\mathrm{CH}\left(\mathrm{OCH}_{3}\right) \mathrm{CH}_{2} \mathrm{Cl} O \mathrm{CH}_{3}$. i. $\left.\neg=0 . \mathrm{m}.\right\rangle=\mathrm{O}$

In conclusion, the Lewis acid-catalyzed reaction of anthrone with $\alpha, \beta$-unsaturated ester gave bridged compounds (Diels-Alder adduct type), in which the ring could easily be opened by a catalytic amount of base, and mono-Michael adduct exclusively, while the base-catalyzed reaction gave 10.10-bis-Michael adduct as a major product independent of
Table 4. Base-catalyzed consecutive conjugated addition of anthrone with ethylenic substrates

\begin{tabular}{|c|c|c|c|c|c|}
\hline \multirow{2}{*}{ Entry } & \multirow{2}{*}{ sthylenic substrate } & \multicolumn{2}{|c|}{ Conditionst } & \multicolumn{2}{|c|}{ product. \% } \\
\hline & & base $^{h}$ & lime (h) & 12 & 13 \\
\hline 1 & methyl acrylate (a) & NaOMe & 5 & 91 & 0 \\
\hline$\underline{2}$ & ethyl acrylate (h) & $\mathrm{NaOlit}$ & 4 & 93 & 0 \\
\hline 3 & ethyl methacrylate (c) & $\mathrm{NaOl}: \mathrm{t}$ & 2 & 51 & 0 \\
\hline 4 & methyl vinyl kelone (d) & NaOMe & 5 & 89 & 5 \\
\hline 5 & ethyl ving] ketone (e) & NaOMe & 4 & 88 & $\operatorname{tr}$ \\
\hline 6 & phenyl viny] ketone (f) & NialoMe & 3 & 50 & 0 \\
\hline 7 & acrylonitrile (g) & NaOMe & 5 & 96 & 0 \\
\hline 8 & phenyl viny] sulfone (h) & $\mathrm{NaOMe}$ & 48 & 90 & 0 \\
\hline 9 & methyl crotonale (i) & $\mathrm{NaOMe}$ & 2 & 0 & 53 \\
\hline 10 & methyl $-3-3$-methoxyacrylate $(\mathrm{j})$ & $\mathrm{NaOMe}$ & 2 & 0 & 45 \\
\hline 11 & cyclopentenone $(\mathbf{k})$ & NaOMe & 3 & 0 & 85 \\
\hline 12 & cyclohexenone (I) & NaOMe & 3 & 0 & 80 \\
\hline
\end{tabular}

"Reaction mixtutes were refluxed, except with phenyl viny] sulfone (at room temperature). "Catalytic amounts (approx. 0.1 mol\%) of base were used. "Isolated yield

the amount of ethylenic substrate and base. Further Michael reaction of mono-Michael adducts with different ethylenic substrates in the presence of a catalytic amount of alkoxide gave unsymmetrical 10,10-bis Michael adducts.

\section{Experimental Section}

NMR spectra were recorded on a Varian Gemini-200 spectrometer in $\mathrm{CDCl}_{3 .}$. IR spectra were obtained using a Perkin-ГImer Paragon 1000 spectrometer. Mass spectra were obtained at a $70 \mathrm{eV}$ via GC-MS coupling, GC analyses were performed using a capillary column ( $25 \mathrm{~m} \times 0.2 \mathrm{~mm}$ i.d.). Melting points were determined on a Mel-Temp II apparatus and are uncorrected. All reagents were used as purchased and solvents were purified by conventional methods. All conjugated addition reactions were performed under dry nitrogen.

General procedure for the Lewis acid-catalyzed monoMichael reaction of anthrone. A solution of anthrone $(500$ mg, $2.57 \mathrm{mmol})$ in methanol $(5.0 \mathrm{~mL})$ was treated with methyl acrylate $(1.06 \mathrm{~mL}, 11.8 \mathrm{mmol})$ and $\angle \mathrm{nCl}_{2}(5.0 \mathrm{mg}$, $0.04 \mathrm{mmol}$ ). The mixture was refluxed for $3 \mathrm{~h}$ and then concentrated under vacuum. The residue was extracted with methylene chloride, and then washed with brine. The organic phase was dried over $\mathrm{MgSO}_{4}$, filtered, and concentrated. Chromatography (10\% EtOAc in n-hexane) gave 10-(2'methoxycarbonyl)ethyl-9 (10H)-anthracenone 4a (26 mg. 4 $\%$ ) as an oil. methyl 9,10-dihydro-9-hydroxy-9,10-ethanoanthracene-11-carboxylate $\mathbf{3 a}(592 \mathrm{mg}, 83 \%)$ as a white solid, and 10-(2'-methoxycarbonyl)ethyl-9-hydroxyanthracene $5 \mathbf{a}(15 \mathrm{mg}, 2 \%)$ as an oil.

Compound 3a: TLC $R_{f} 0.48$ (25\% EtOAc in $n$-hexane); mp 12]-123 ' C; [R (KBr) 3429, 1696, 1458, 1309, I26] $\mathrm{cm}^{-1} ;{ }^{\mathrm{H}} \mathrm{H} \mathrm{NMR}\left(\mathrm{CDCl}_{3}\right) \delta 7.67(\mathrm{~d}, J=8.7 \mathrm{~Hz}, 1 \mathrm{H}), 7.56(\mathrm{~d}, J$ $=8.5 \mathrm{~Hz}, 1 \mathrm{H}), 7.31-7.15(\mathrm{~m}, 6 \mathrm{H}), 5.29(\mathrm{~s}, 1 \mathrm{H}), 4.35(\mathrm{t} . J=$ $5.4 \mathrm{~Hz}, \mathrm{lH}), 3.59(\mathrm{~s}, 3 \mathrm{H}), 2.93(\mathrm{t}, J=7.8 \mathrm{~Hz}, \mathrm{lH}), 2.25(\mathrm{dd}, J$ 
$=1.2$ and $7.7 \mathrm{~Hz} .2 \mathrm{H}):{ }^{13} \mathrm{C}$ NMR $\left(\mathrm{CDCl}_{\hat{3}}\right) \delta 176.3 .144 .8$. $143.4,128.0,127.5,124.7,124.5 .122 .6 .122 .0 .78 .4,53.8$. 49.9, 44.4. 33.0. MS $m=281\left(\mathrm{M}^{+}+1\right) .250 .194,165,139$. 82.

Compound 4a: TLC $R_{f} 0.44$ (25\% EtOAc in $n$-hexane): IR $(\mathrm{KBr}) 1735,1665.1601,1463.1315 \mathrm{~cm}^{-1}:{ }^{1} \mathrm{H}$ NMR $\left(\mathrm{CDCl}_{3}\right) \delta 8.30(\mathrm{~d}, J=7.7 \mathrm{~Hz}, 2 \mathrm{H}) .7 .66-7.57(\mathrm{~m} .3 \mathrm{H}) .7 .51-$ 7.42 (m. 3H) 4.42 (t. $J=5.3 \mathrm{~Hz} . \mathrm{lH}$ ). 3.50 (s. $3 \mathrm{H}), 2.40$ $2.29(\mathrm{~m}, 2 \mathrm{H}) .1 .88(\mathrm{t}, J=7.9 \mathrm{~Hz} .2 \mathrm{H}) ;{ }^{13} \mathrm{C} \mathrm{NMR}\left(\mathrm{CDCl}_{3}\right) \delta$ $183.0,174.8,145.4 .134 .7,134.0 .129 .7,129.1 .128 .9,53.1$. $42.8,37.8$. 30.6; MS $m z 281\left(\mathrm{M}^{+}+1\right) .250 .195,163,139$. 115.

Compound 5a: TLC $R_{f} 0.16$ (25\% EtOAc in $n$-hexane): IR (KBr) 3384, 1711. 1664, 1601. $1318 \mathrm{~cm}^{-1}:{ }^{1} \mathrm{H}$ NMR $\left(\mathrm{CDCl}_{3}\right) \delta 8.30(\mathrm{~d}, J=9.5 \mathrm{~Hz}, 2 \mathrm{H}) .8 .14(\mathrm{~s}, \mathrm{lH}) .7 .87(\mathrm{~d} . J=$ $9.1 \mathrm{~Hz} .2 \mathrm{H}) .7 .74$ (t. $J=9.3 \mathrm{~Hz} .2 \mathrm{H}) .7 .61(\mathrm{t}, J=8.2 \mathrm{~Hz} .2 \mathrm{H})$. 3.43 (s. $3 \mathrm{H}), 2.37 .2 .29(\mathrm{~m}, 2 \mathrm{H}) .1 .81-1.73(\mathrm{~m}, 2 \mathrm{H}) ;{ }^{13} \mathrm{C}$ NMR $\left(\mathrm{CDCl}_{3}\right) \delta 173.8 .144 .2 .135 .7,133.9,130.4,129.2$. 127.1, 53.3. 40.4, 30.0; MS $m z 280\left(\mathrm{M}^{+}\right) .248,191,178$. 136.

Data of compound $3 \mathbf{b}$ and $3 \mathbf{c}$ have been reported in reference 11

Compound 3d: TLC $R_{f} 0.24$ (2.5\% EtOAc in benzene): mp $212-215{ }^{\circ} \mathrm{C}$; IR (KBr) $3404,2243.1458 .1246,1239$ $\mathrm{cm}^{-1} ;{ }^{1} \mathrm{H} \mathrm{NMR}\left(\mathrm{CDCl}_{\hat{3}}\right) \delta 7.62(\mathrm{~d} . J=6.6 \mathrm{~Hz}, 1 \mathrm{H}), 7.53(\mathrm{~d} . J$ $=6.4 \mathrm{~Hz} . \mathrm{lH}), 7.38-7.37(\mathrm{~m}, 2 \mathrm{H}), 7.35-7.18(\mathrm{~m}, 5 \mathrm{H}), 4.46(\mathrm{~s}$. $1 \mathrm{H}), 3.10(\mathrm{dd}, J=4.5$ and $10.5 \mathrm{~Hz} .1 \mathrm{H}), 2.28(\mathrm{t} . J=14.0 \mathrm{~Hz}$. lH), $1.89-1.30(\mathrm{~m}, \mathrm{lH}):{ }^{13} \mathrm{C}$ NMR $\left(\mathrm{CDCl}_{3}\right) \delta 1+4.6,142.8$. $142.7,142.6 .127 .9,127.1,127.0,124.5,122.9,122.8$. $121.8,77.3,42.5,37.1 .35 .3 ; \mathrm{MS} m z 248\left(\mathrm{M}^{-}+\mathrm{l}\right), 208.193$. 165. 139.

Compound 3f: TLC $R_{f} 0.45$ (25\% EtOAc in $n$-hexane): mp 107-108 ${ }^{\circ} \mathrm{C}$; IR $(\mathrm{KBr}) 3448,1718.1690 .1450 .1258$. $1186 \mathrm{~cm}^{-1} ;{ }^{1} \mathrm{H} \mathrm{NMR}\left(\mathrm{CDCl}_{3}\right): \delta 7.69(\mathrm{~d} . J=8.7 \mathrm{~Hz}, \mathrm{lH})$. $7.56($ d. $J=8.6 \mathrm{~Hz}, 1 \mathrm{H}), 7.68-7.54(\mathrm{~m}, 6 \mathrm{H}), 5.29(\mathrm{~s} . \mathrm{HH})$. $4.31(\mathrm{t} . J=5.6 \mathrm{~Hz}, 1 \mathrm{H}), 4.09-3.98(\mathrm{~m}, 2 \mathrm{H}) .2 .92-2.83(\mathrm{~m}$. $2 \mathrm{H}), 2.26-2.17$ (m. $2 \mathrm{H}$ ), 1.12 (t. $J=7.2 \mathrm{~Hz} .3 \mathrm{H}$ ): ${ }^{13} \mathrm{C}$ NMR $\left(\mathrm{CDCl}_{3}\right) \delta 175.7,144.7,143.6 .143 .5,143.2,127.9 .127 .8$. 127.5, 127.4. 124.5. 124.4. 122.5, 122.0, 62.9, 50.0. 44.3. $33.8,15.6 ; \mathrm{MS} m z 295\left(\mathrm{M}^{-}+1\right), 195.166,139.82$.

Compound +f: TLC $R_{f} 0.34$ ( $25 \%$ EtOAc in $n$-hexane): IR (KBr) 1732, 1665. 1602, 1463. $1315 \mathrm{~cm}^{-1}:{ }^{1} \mathrm{H}$ NMR $\left(\mathrm{CDCl}_{3}\right) \delta 8.32(\mathrm{~d}, J=9.1 \mathrm{~Hz}, 2 \mathrm{H}) \cdot 7.66-7.43(\mathrm{ml} .6 \mathrm{H}) .4 .43$ (t. $J=5.4 \mathrm{~Hz}, 1 \mathrm{H}$ ), 3.93 (q. $J=7.1 \mathrm{~Hz}, 2 \mathrm{H}$ ), 2.33-2.29 (m. $2 \mathrm{H}), 1.89-1.81$ (m. $2 \mathrm{H}), 1.15$ (t. $J=7.1 \mathrm{~Hz} .3 \mathrm{H}$ ): ${ }^{13} \mathrm{C}$ NMR $\left(\mathrm{CDCl}_{3}\right) \delta 185.9,174.3,145.4 .134 .8,133.9,129.8 .129 .0$. $128.8,82.0 .42 .8 .37 .7,30.8 .15 .7$; MS $m=295\left(\mathrm{M}^{+}+1\right) .265$. 250. 208, 194. 178, 166. 139.

Compound 5f: TLC $R_{f} 0.25$ ( $25 \%$ EtOAc in $n$-hexane): IR (KBr) 3304. 1613, 1582. 1284, 1228, $1209 \mathrm{~cm}^{-1}:{ }^{1} \mathrm{H}$ NMR $\left(\mathrm{CDCl}_{\mathfrak{s}}\right) \delta 8.32($ d. $J=7.7 \mathrm{~Hz} .2 \mathrm{H}) .8 .00$ (s. $\left.\mathrm{HH}\right), 7.88$ $($ d. $J=7.8 \mathrm{~Hz}, 2 \mathrm{H}), 7.75$ (t. $J=8.3 \mathrm{~Hz}, 2 \mathrm{H}), 7.56$ (t. $J=7.5$ $\mathrm{Hz}, 2 \mathrm{H}) .3 .88$ (q, $J=7.2 \mathrm{~Hz}, 2 \mathrm{H}) .2 .34(\mathrm{t}, J=8.1 \mathrm{~Hz}, 2 \mathrm{H})$. $1.76(\mathrm{t} . J=8.3 \mathrm{~Hz}, 2 \mathrm{H}) .1 .09(\mathrm{t}, J=7.2 \mathrm{~Hz}, 3 \mathrm{H}),{ }^{13} \mathrm{C}$ NMR $\left(\mathrm{CDCl}_{3}\right) \delta 173.4,144.2,135.7 .135 .3,134.0,130.4 .129 .2$. 128.8, 127.1. 62.2, 40.3. 30.4. 15.0. MS $m=295\left(\mathrm{M}^{+}+1\right)$. 265. $210,181.152,126.95$.
Compound 3g: TLC $R_{f} 0.38$ (benzene); mp 117-119 ${ }^{\circ} \mathrm{C}$; IR (KBr) 3373. 1689, 1485. 1315, $1253 \mathrm{~cm}^{-1}:{ }^{1} \mathrm{H}$ NMR $\left(\mathrm{CDCl}_{3}\right) \delta 7.73($ d. $J=6.9 \mathrm{~Hz} . \mathrm{lH}) .7 .58($ d. $J=6.6 \mathrm{~Hz} . \mathrm{lH})$, 7.33-7.17 (m. $6 \mathrm{H}), 5.37$ (s. lH). 4.32 (t. $J=2.7 \mathrm{~Hz} . \mathrm{lH}$ ), 2.82 (dd. $J=4.3$ and $10.2 \mathrm{~Hz} .1 \mathrm{H}$ ). $2.35(\mathrm{t}, J=3.5 \mathrm{~Hz}, 1 \mathrm{H}$ ), $2.29(\mathrm{t}, J=3.6 \mathrm{~Hz}, \mathrm{lH}) \cdot 2 \cdot 16-2.03(\mathrm{~m}, \mathrm{lH}) .1 .33(\mathrm{~s}, 9 \mathrm{H}) \cdot{ }^{13} \mathrm{C}$ NMR $\left(\mathrm{CDCl}_{3}\right) \delta$ 174.5. 144.8. 144.0. 143.7, 143.1, 127.9. 127.8, 127.4. 127.3. 124.6. 124.2. 122.5, 122.1, 84.5. 78.7 , 50.6. 44.3. 33.8, 30.5; MS $m=323\left(\mathrm{M}^{-}+1\right), 267.250 .232$. 207. 193. 165 .

Compound 4g: TLC $R_{f} 0.23$ (benzene); IR (KBr) 1727 , 1666. 1602, 1462.1368, 1315.1147 $\mathrm{cm}^{-1}$; ${ }^{\mathrm{j}} \mathrm{H} \mathrm{NMR}\left(\mathrm{CDCl}_{3}\right)$ $\delta 8.28($ d. $J=7.7 \mathrm{~Hz} .2 \mathrm{H}) .7 .59-7.39(\mathrm{~m}, 6 \mathrm{H}) .4 .37(\mathrm{t}, J=5.0$ Hz. $1 \mathrm{H}) .2 .24-2.23(\mathrm{~m}, 2 \mathrm{H}), 1.81-1.77(\mathrm{~m}, 2 \mathrm{H}) .1 .33(\mathrm{~s}, 9 \mathrm{H})$; ${ }^{13} \mathrm{C}$. NMR $\left(\mathrm{CDCl}_{2}\right) \delta 186.0 .173 .8 .145 .7 .134 .6,134.0$, $129.8,129.0,128.8 .127 .7 .127 .6,127.2 .122 .5 .122 .2$, $122.1,82.0,42.9 .37 .9 .32 .0,29.8$. MS $m z 323\left(\mathrm{M}^{+}+1\right) .267$. 250.232.207, 195. 163

Compound 3h: TLC $R_{f} 0.31$ (benzene); mp 156-158 ${ }^{\circ} \mathrm{C}$ (lit ${ }^{13}$ : 154-158 ${ }^{\circ} \mathrm{C}$ ): IR (KBr) 1772. 1670. 1599. $1312 \mathrm{~cm}^{-1}$; ${ }^{1} \mathrm{H}$ NMR $\left(\mathrm{CDCl}_{3}\right) \delta 8.31-8.26$ (m. $\left.2 \mathrm{H}\right), 7.63 .7 .39(\mathrm{~m} .6 \mathrm{H})$, $4.25(\mathrm{~d}, J=5.8 \mathrm{~Hz}, \mathrm{lH}) .4 .02(\mathrm{~d} . J=6.0 \mathrm{~Hz} .2 \mathrm{H}) .2 .82(\mathrm{q} . J$ $=7.9 \mathrm{~Hz} \cdot \mathrm{lH}) \cdot 2.39-2.34(\mathrm{~m}, 2 \mathrm{H}) \cdot{ }^{12} \mathrm{C} \mathrm{NMR}\left(\mathrm{CDCl}_{3}\right) \delta$ $183.0,176.8,143.1 .142 .6 .134 .6,134.5 .133 .8 .130 .1$, 129.9. 129.7. 129.5. 128.2. 71.7. 48.1. 46.6. 34.3: MS $m z$ $279\left(\mathrm{M}^{+}+1\right) .193,165.139,115$

Compound trans-3i: TLC $R_{f} 0.23(2.5 \%$ EtOAC in benzene): $\operatorname{mp} 241-244^{\circ} \mathrm{C}$; $\mathrm{IR}(\mathrm{KBr}) 3470,1735.1459 .1293$, $1216 \mathrm{~cm}^{-1}:{ }^{1} \mathrm{H}$ NMR $\left(\mathrm{CDCl}_{3}\right) \delta 7.74-7.69(\mathrm{~m}, \mathrm{lH}), 7.62-$ $7.57(\mathrm{~m} . \mathrm{lH}), 7.40(\mathrm{~s}, 2 \mathrm{H}) .7 .25-7.18(\mathrm{~m} .4 \mathrm{H}), 5.40(\mathrm{~s} . \mathrm{lH})$, $4.74(\mathrm{~d} . J=2.6 \mathrm{~Hz}, 1 \mathrm{H}) .3 .68(\mathrm{~s}, 3 \mathrm{H}) \cdot 3.52-3.50(\mathrm{~m}, 2 \mathrm{H}):{ }^{13} \mathrm{C}$ NMR $\left(\mathrm{CDCl}_{3}\right) \delta$ 175.1. 173.7. 144.4. 144.0, 141.6, 139.9. 130.0, 128.2. 128.1. 125.4. 125.0. 122.7, 122.2, 78.3. 54.2, 54.1. 52.9. 50.9, 47.3; MS $m=339\left(\mathrm{M}^{-}+1\right), 322.265 .219$. 194. 165.127

Compound trans-3j: TLC $R_{f} 0.27(2.5 \%$ EtOAc in benzene): $m p$ 73-75 ${ }^{\circ} \mathrm{C}$; IR (KBr) 3497, 1738. 1712. 1459 . 1369. $1231,1205 \mathrm{~cm}^{-1} ;{ }^{1} \mathrm{H}$ NMR $\left(\mathrm{CDCl}_{3}\right) \delta 7.69($ d. $J=7.0$ Hz. lH), $7.54(\mathrm{~d}, J=7.3 \mathrm{~Hz}, \mathrm{lH}), 7.37-7.33(\mathrm{~m}, \mathrm{lH}) .7 .23-$ $7.15(\mathrm{~m} .5 \mathrm{H}), 5.36(\mathrm{~s}, \mathrm{lH}) .4 .69(\mathrm{~s}, \mathrm{lH}) .4 .10-4.30(\mathrm{~m} .4 \mathrm{H})$. 3.47 (s. $2 \mathrm{H}$ ). 1.23 (t. $J=7.1 \mathrm{~Hz}, 3 \mathrm{H}$ ). 1.11 (t. $J=7.1 \mathrm{~Hz}$. $3 \mathrm{H}) ;{ }^{13} \mathrm{C} \mathrm{NMR}\left(\mathrm{CDCl}_{3}\right) \delta 174.5 .173 .2,144.3,144.1 .141 .6$, $139.9,128.2$. 128.1, 128.0. 125.4, 125.0. 122.5, 122.2, 63.3, 62.9. 62.8, 52.9, 50.7, 47.3. 15.9. 15.6: MS $m z 367\left(\mathrm{M}^{-}+1\right)$, $338.322 .219,194.165,127$

Formation of cross-coupled anthrones 11. General procedure for the direct fomation of unsymmetrical 10.10disubstituted anthrone derivatives: (Reaction of 10-monoMichael adduct with alkenes under LiHMDS conditions in Case a).

LiHMDS (1.6 M THF solution of lithium bis(tmethylsilyl)amide) was added dropwise to a mixture of mono-Michael adduct $+(1$ eq) and ethylenic carbonyl compounds (ethyl acrylate. methyl acrylate and methyl vinyl ketone, $2.5 \mathrm{eq}$ ) in freshly distilled THF $(0.1 \mathrm{M})$ at $0^{\circ} \mathrm{C}$. The reaction mixture was allowed to warm up to $\mathrm{rt}$ and then stirred until the reaction was completed. Next, water was poured into the 
flask. which was then extracted with methylene chloride. The separated organic layer was washed with a brine solution. dried over sodium sulfate and purified by flash columin chrontatography to give unsynmetrical 10.10disubstituted anthrones (11).

Compound 11 a: Yield 30\%; TLC Rf 0.63 (EtOAc : nHexane = I: 1); np 143-145 ${ }^{\circ} \mathrm{C} ;$ IR $(\mathrm{KBr}) 2947,1732$. $1661,1602,1457,1369,1322,1280,1175 \mathrm{~cm}^{-1}:{ }^{1} \mathrm{H}$ NMR

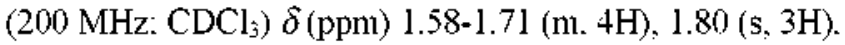
2.51-2.65 (nl. $4 \mathrm{H}), 3.44(\mathrm{~s}, 3 \mathrm{H}), 7.26-7.53(\mathrm{~m}, 2 \mathrm{H}) .7 .6 \mathrm{l}-$ $7.71(\mathrm{~m}, 4 \mathrm{H}) .8 .41(\mathrm{~d}, J=8 \mathrm{~Hz}, 2 \mathrm{H}) ;{ }^{13} \mathrm{C}$ NMR $(75 \mathrm{MHz}$ : $\left.\mathrm{CDCl}_{3}\right) \delta 183.0,172.9,145.1,134.2,132.4 .127 .5 .127 .3$. $125.8,51.3 .44 .4,39.7 .38 .3 .38 .1,29.7 .29 .0 ;$ MS $m: z 380$ $\left(\mathrm{M}^{+}\right), 301,291.279,263$

Compound 11b: Yield 57\%; TLC R 0.60 (EtOAc : nHexane = 1: 1): mp 97-100 ${ }^{\circ} \mathrm{C}:$ IR $(\mathrm{KBr}) 1735,1659.1600$. 1457, 1372, 1323. 1188, $1031 \mathrm{~cm}^{-1}$ : ${ }^{1} \mathrm{H}$ NMR $(200 \mathrm{MHz}$ : $\left.\mathrm{CDCl}_{3}\right) \delta(\mathrm{ppm}) 1.08(\mathrm{t}, J=7.2 \mathrm{~Hz}, 3 \mathrm{H}), 1.54-1.64(\mathrm{~m} .4 \mathrm{H})$. 2.62 (t. $J=7.8 \mathrm{~Hz}, 4 \mathrm{H}$ ). 3.44 (s. $3 \mathrm{H}$ ), 3.89 (q, $J=7.1 \mathrm{~Hz}$. $2 \mathrm{H}), 7.49-7.53(\mathrm{~m}, 2 \mathrm{H}), 7.63-7.71(\mathrm{~m}, 4 \mathrm{H}), 8.40(\mathrm{~d}, J=7.8$ $\mathrm{Hz}, 2 \mathrm{H}):{ }^{13} \mathrm{C}$ NMR $\left(75 \mathrm{MHz} ; \mathrm{CDCl}_{3}\right) \delta 183.0,172.7 .144 .8$. 134.3, 133.6. 128.2. 127.6. 127.0, 125.8, 60.3, 51.4. 44.7. $39.7,39.6,29.2,29.1,13.9$ : MS $m z 380\left(\mathrm{M}^{+}\right), 349.293$. 279. 219.

Compound 11e: Yield 44\%: TLC $\mathrm{R}_{\mathrm{f}} 0.30$ (EtOAc : nHexane = 1: 1): mp $122-123^{\circ} \mathrm{C}$; IR (KBr) 1712. 1661, 1321 $\mathrm{cm}^{-1}$; ${ }^{1} \mathrm{H}$ NMR (200 MHz: $\left.\mathrm{CDCl}_{3}\right) \delta(\mathrm{ppm}) 1.08(\mathrm{t}, J=7.2$ Hz, 3H). 1.51-1.71 (nt. 4H), 1.80 (s. 3H), $2.51-2.65$ (m, $4 \mathrm{H})$. 3.89 (q. $J=7.2 \mathrm{~Hz} .2 \mathrm{H}), 7.45-7.53$ (m. $2 \mathrm{H}), 7.61-7.75(\mathrm{~m}$. $4 \mathrm{H}), 8.41(\mathrm{~d}, J=7.8 \mathrm{~Hz} .2 \mathrm{H}):{ }^{13} \mathrm{C}$ NMR (75 MHz: DMSO) $\delta$ $144.1,142.7,142.5,142.3,126.5 .126 .4,125.5,121.4$. $121.0,120.4,75.1,42.9 .38 .3,36.8,36.5 .30 .0 .23 .0 . \mathrm{MS} m z$ $380\left(\mathrm{M}^{-}\right), 319.307,293.263$.

General experimental procedure in Case B. LiHMDS (1.6 M THF solution of lithium bis(trmethylsilyl)anide) was added dropwise to a mixture of mono-Michael adduct 4 (1 eq) and acrylonitrile (2.5 eq) in freshly distilled THF (0.1 M) at $0^{\circ} \mathrm{C}$. The reaction mixture was allowed to wann up to $\mathrm{rt}$ and stirred. After the reaction was completed. water was poured into the flask, which was then extracted with methylene chloride. The separated organic layer was washed with brine, dried over sodium sulfate and purified by recrystallization to give unsymmetrical 9.10-bridged anthrones (10).

Compound 10d: Yield 85\%: TLC $R_{f} 0.26$ (Chloroform methanol = $13: 1)$; mp 189-191 ${ }^{\circ} \mathrm{C} ; \mathrm{IR}(\mathrm{KBr}) 3427.2256$. 1737, 1456, $1175 \mathrm{~cm}^{-1}$; ${ }^{1} \mathrm{H}$ NMR (200 MHz: $\left.\mathrm{CDCl}_{\mathfrak{j}}\right) \delta$ (ppn) 1.88 (dd, $J=7.2 \mathrm{~Hz}, 4.9 \mathrm{~Hz}, 1 \mathrm{H}), 2.12$ (t. $J=11.7 \mathrm{~Hz}$. lH) $2.73-2.93$ (m. $4 \mathrm{H}) .3 .09$ (q. $J=4.9 \mathrm{~Hz}, \mathrm{lH}) .3 .34$ (s. $1 \mathrm{H}-\mathrm{OH}), 3.81$ (s. $3 \mathrm{H}) .7 .21-7.35(\mathrm{~m}, 6 \mathrm{H}), 7.57$ (d. $J=5.2$ $\mathrm{Hz}, 1 \mathrm{H}$ ). 7.61 (d. $J=4.6 \mathrm{~Hz}, 1 \mathrm{H}$ ); ${ }^{13} \mathrm{C}$ NMR $(75 \mathrm{MHz}$ : DMSO-d 6 ) $\delta 173.5 .144 .1,142.3 .142 .2,126.4 .125 .5,125.4$. $121.5,121.2,120.9,120.5,75.0 .54 .9,51.6 .42 .7 .36 .4,29.1$. 24.9: $\mathrm{MS} m z 333\left(\mathrm{M}^{+}\right) .302,293.279 .246$.

Compound 10e: Yield 84\%: TLC $R_{f} 0.33$ (EtOAc : nHexane = I: 1); mp 184-186 ${ }^{\circ} \mathrm{C} ; \mathrm{IR}(\mathrm{KBr}) 3397,2253$. 1735, 1456, $1178 \mathrm{~cm}^{-1}$; ${ }^{1} \mathrm{H}$ NMR $\left(200 \mathrm{MHz} \mathrm{CDCl}_{j}\right) \delta$ (ppnt) 1.34 (t. $J=7.3 \mathrm{~Hz} .3 \mathrm{H}$ ). 1.88 (dd. $J=12.5 \mathrm{~Hz} .4 .9 \mathrm{~Hz}$.
1H). $2.12(\mathrm{t} . J=11.7 \mathrm{~Hz} .1 \mathrm{H}), 2.73-2.93(\mathrm{~m}, 4 \mathrm{H}), 3.09(\mathrm{q} . J$ $=4.9 \mathrm{~Hz} . \mathrm{lH}) .3 .40(\mathrm{~s}, 1 \mathrm{H}-\mathrm{OH}), 4.26(\mathrm{q}, J=4.3 \mathrm{~Hz}, 2 \mathrm{H})$. $7.21-7.35$ (m. $6 \mathrm{H}$ ). 7.57 (d. $J=5.2 \mathrm{~Hz}, 1 \mathrm{H}$ ). $7.6 \mathrm{l}$ (d. $J=4.6$ Hz. $1 \mathrm{H}) ;{ }^{13} \mathrm{C}$ NMR (75 MHz; DMSO-d $) \delta 173.4$. 142.4, $142.0,141.8,140.8$. 127.1. 127.0, 126.3. 126.1. 121.2. $120.8,120.2,120.0 .76 .05,61.0,43.3,37.5 .36 .7,30.0 .25 .4$, 14.2; $\mathrm{MS} m z 347\left(\mathrm{M}^{-}\right), 303.293 .265,246$.

Compound 10f: Yield 72\%: TLC $R_{f} 0.63$ (EtOAc : n-

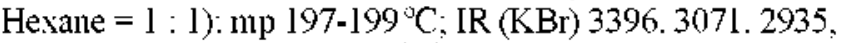
2252. 1713. 1636. $1457 \mathrm{~cm}^{-1}$; ${ }^{1} \mathrm{H} \mathrm{NMR}\left(200 \mathrm{MHz} \mathrm{CDCl}_{3}\right)$ $\delta(\mathrm{ppm}) 1.58(\mathrm{~s}, 3 \mathrm{H}), 1.87$ (dd. $J=12.6 \mathrm{~Hz} .4 .9 \mathrm{~Hz}, 1 \mathrm{H})$, 2.10 (t. $J=12.5 \mathrm{~Hz}, \mathrm{lH}), 2.79-2.84$ (m. 2H). 2.92-2.95 (m, $2 \mathrm{H}) .3 .09(\mathrm{q}, J=4.9 \mathrm{~Hz}, \mathrm{lH}), 3.28(\mathrm{~s}, \mathrm{lH}-\mathrm{OH}), 7.21-7.35$ (m. $6 \mathrm{H}), 7.57$ (d. $J=5.2 \mathrm{~Hz}, 1 \mathrm{H}) .7 .6 \mathrm{l}(\mathrm{d} . J=4.6 \mathrm{~Hz} .1 \mathrm{H})$ : ${ }^{13} \mathrm{C}$ NMR $\left(75 \mathrm{MHz} ; \mathrm{CDCl}_{3}\right) \delta 183.1,172.6 .145 .3 .134 .3$, $132.5,127.6,127.4,125.9,60.3,44.6,39.7 .38 .4,38.3 .29 .8$, 29.3. 14.0: MS $m=333\left(\mathrm{M}^{+}\right)$. 317, 302, 293. 279, 246.

General procedure for the formation of unsymmetrical 10,10-disubstituted anthrone derivatives (11) from the unsymmetrical 9,10-bridged anthrones (10). A catalytic amount of $\mathrm{NaOEt}(2 \mathrm{wt} \%$ solution ethanol) was added to a solution of compound 10 in ethanol $(0.03 \mathrm{M})$. The mixture was refluxed and. after the reaction was completed, allowed to cool down to $0^{\circ} \mathrm{C}$. The reaction mixture was quenched with water. extracted with dichloromethane. washed with brine. dried over sodium sulfate and purified to give the corresponding products 11

Compound 11d: Yield 98\%: TLC $R_{f} 0.56$ (EtOAc : nHexane $=1: 1$ ): np $121-124^{\circ} \mathrm{C}$ : IR $(\mathrm{KBr}) 3445,2263$. 1729. 1660. 1601. 1458. 1324. $1172 \mathrm{~cm}^{-1}$. ${ }^{1} \mathrm{H}$ NMR (200 $\left.\mathrm{MHz} . \mathrm{CDCl}_{2}\right) \delta(\mathrm{ppm})$ 1.54-1.63 (m, 4H), 2.57-2.70 (m, $4 \mathrm{H}) .3 .45$ (s. $3 \mathrm{H}), 7.50-7.65$ (m. $4 \mathrm{H}), 7.72-7.80$ (m. $2 \mathrm{H}$ ), 8.42 (d. $J=7.9 \mathrm{~Hz} .2 \mathrm{H}$ ): ${ }^{13} \mathrm{C} \operatorname{NMR}\left(75 \mathrm{MHz} . \mathrm{CDCl}_{3}\right) \delta$ 182.5, 172.8, 143.3. 134.7. 132.6, 128.1. 128.1. 125.6, $118.7,51.6,44.8,40.5$. 39.5. 28.9. 12.5; MS mz $333\left(\mathrm{M}^{-}\right)$, 302. 293. $279,246$.

Compound 11e : Yield 82\%; TLC $R_{f} 0.66$ (EtOAc : nHexane $=1: 1): \operatorname{mp} 92-95^{\circ} \mathrm{C} ; \mathrm{IR}(\mathrm{KBr}) 3432.2247 .1676$ $\mathrm{cm}^{-1}$. ${ }^{1} \mathrm{H}$ NMR (200 MHz: $\left.\mathrm{CDCl}_{2}\right) \delta(\mathrm{ppm})$ 1.59-1.72 (m, $4 \mathrm{H}) .1 .81$, (s. $3 \mathrm{H}) \cdot 2.50-2.66(\mathrm{~m}, 4 \mathrm{H}) .7 .55-7.63(\mathrm{~m}, 4 \mathrm{H})$. $7.71-7.75$ (m. 2H). 8.43 (d, $J=7.9 \mathrm{~Hz}, 2 \mathrm{H}) ;{ }^{13} \mathrm{C}$ NMR $(75$ $\left.\mathrm{MHz} . \mathrm{CDCl}_{3}\right) \delta$ 143.7. 134.8, 132.6. 128.1, 128.0. 125.6, 44.6. 40.6, 38.2. 38.0. 29.8. 12.6: MS $m=333\left(\mathrm{M}^{+}\right) .317$ 302. 293. $279,246$.

Compound 11f: Yield 98\%; TLC $R_{f} 0.55$ (EtOAc : nHexane $=1: 1)$ : mp $117-120^{\circ} \mathrm{C}$ : IR $(\mathrm{KBr}) 1622,1601$, 1459. $1324 \mathrm{~cm}^{-1}$; ${ }^{l} \mathrm{H}$ NMR (200 MHz: $\left.\mathrm{CDCl}_{3}\right) \delta(\mathrm{ppm}) 1.09$ (t. $J=7.2 \mathrm{~Hz}, 3 \mathrm{H}) .1 .54-1.63(\mathrm{~m}, 4 \mathrm{H}) .2 .57-2.71(\mathrm{~m}, 4 \mathrm{H})$. 3.90 (q. $J=7.0 \mathrm{~Hz}, 2 \mathrm{H}), 7.50-7.66(\mathrm{~m}, 4 \mathrm{H}) .7 .72-7.81(\mathrm{~m}$, $2 \mathrm{H}) .8 .42(\mathrm{~d} . J=7.97 \mathrm{~Hz} .2 \mathrm{H}) ;{ }^{13} \mathrm{C}$ NMR $\left(75 \mathrm{MHz}_{;} \mathrm{CDCl}_{3}\right)$ $\delta$ 172.4. 143.4. 134.7. 128.1. 128.1, 125.6, 76.6. 60.5. 40.6, 39.4. 29.1, 13.9. 12.5; MS $m=333\left(\mathrm{M}^{+}\right), 303.293,246$.

General procedure for the base-catalyzed Michael reaction; formation of bis-Michael adducts (12a-12h) and/or mono-Michael adducts (12i-12]). A mixture of antlurone (500 mg. $2.57 \mathrm{mmol}$ ). methyl acrylate (1.05 mL. $11.58 \mathrm{mmol}$ ) and sodium methoxide (23 $\mathrm{mg} .0 .34 \mathrm{mmol}) \mathrm{in}$ 
methanol $(5.0 \mathrm{~mL})$ was refluxed for $5 \mathrm{~h}$ and then concentrated under reduced pressure. The residue was chromatographed over silica gel ( $10 \%$ EtOAc in $n$-hexane) to give compound 12a (856 $\mathrm{mg}, 91 \%$ ) as a white solid.

Compound 12a(Bis-Michael adduct): TLC $R_{f} 0.3$ (10\% EtOAc in $n$-hexane); mp $116-118{ }^{\circ} \mathrm{C}$ : IR (KBI) 1736, 1668. $1324,1196 \mathrm{~cm}^{-1}:{ }^{1} \mathrm{H}$ NMR (200 MHZ; $\left.\mathrm{CDCl}_{3}\right) \delta 8.40(\mathrm{~d} . J=$ $9.1 \mathrm{~Hz}, 1 \mathrm{H}) .7 .71-7.52(\mathrm{~m}, 2 \mathrm{H}) .7 .51-7.46(\mathrm{~m}, \mathrm{lH}) .3 .42(\mathrm{~s}$. $3 \mathrm{H}), 2.65-2.57(\mathrm{~m} .2 \mathrm{H}) .1 .59-1.54(\mathrm{~m}, 2 \mathrm{H}) ;{ }^{13} \mathrm{C}$ NMR $(50$ $\left.\mathrm{MHZ}: \mathrm{CDCl}_{3}\right) \delta 184.6,174.7 .146 .4$. 135.9. 134.9. 134.3. $129.3,129.1,127.5,53.1 .46 .4$. 41.4, 30.7; MS $m z 367$ $\left(\mathrm{M}^{+}+1\right), 336.304,280,220.189$.

Compound 12b(Bis-Michael adduct): TLC $R_{f} 0.42$ (25 $\%$ EtOAc in $n$-hexane): mp 109-111 ${ }^{\circ} \mathrm{C}$ : IR (KBr) 1734. $1660,1601.1458,1324.1187 \mathrm{~cm}^{-1}:{ }^{1} \mathrm{H}$ NMR $\left(\mathrm{CDCl}_{3}\right) \delta$ $8.40(\mathrm{~d}, J=9.0 \mathrm{~Hz}, \mathrm{IH}) .7 .71-7.52$ (m. $2 \mathrm{H}) .7 .52-7.27$ (m. lH), $3.90(\mathrm{q}, J=7.1 \mathrm{~Hz}, 2 \mathrm{H}) .2 .65-2.57$ (m. $2 \mathrm{H}), 1.61-1.53$ (m. $2 \mathrm{H}$ ). 1.09 (t. $J=7.1 \mathrm{~Hz} .3 \mathrm{H}) ;{ }^{13} \mathrm{C}$ NMR $\left(\mathrm{CDCl}_{3}\right) \delta$ 184.6, 174.3, 146.6. 135.9, 134.3. 129.3, 129.0. 127.9, 61.9. $46.4,30.0$. 15.6; MS $m z 395\left(\mathrm{M}^{+}+1\right) .350 .294,248,220$. 190.

Compound 12c(Bis-Michael adduct): TLC $R_{f} 0.21$ (25 $\%$ EtOAc in $n$-hexane): mp 121-126 ${ }^{\circ} \mathrm{C}$ : IR (KBr) 1718 . $1664,1458,1381,1176 \mathrm{~cm}^{-1} .{ }^{1} \mathrm{H} \mathrm{NMR}\left(\mathrm{CDCl}_{3}\right) \delta 8.39(\mathrm{~d}, J$ $=4.5 \mathrm{~Hz} . \mathrm{lH}), 7.66-7.60(\mathrm{~m} .2 \mathrm{H}) .7 .50-7.44(\mathrm{~m}, 1 \mathrm{H}), 3.56-$ $3.49(\mathrm{~m}, \mathrm{lH}) .3 .28-3.19(\mathrm{~m} . \mathrm{lH}) .2 .89-2.77(\mathrm{~m}, \mathrm{lH}) .2 .24$ (dd. $J=6.0$ and $14.0 \mathrm{~Hz} . \mathrm{lH}), 1.76-1.60(\mathrm{~m} . \mathrm{lH}), 0.9 \mathrm{l}(\mathrm{t}, J=$ $7.1 \mathrm{~Hz}, 3 \mathrm{H}), 0.76(\mathrm{~d}, J=7.0 \mathrm{~Hz} .3 \mathrm{H}) ;{ }^{13} \mathrm{C} \mathrm{NMR}\left(\mathrm{CDCl}_{\mathrm{s}}\right) \delta$ $184.8,177.6,146.3,134.9,134.4 .130 .0,128.9 .128 .8,61.7$. 50.5, 46.9. 37.4. 21.1. 15.2: $\mathrm{MS} m z 423\left(\mathrm{M}^{-}+\mathrm{l}\right), 308,234$. 178.

Compound 12d(Bis-Michael adduct): TLC $R_{f} 0.21$ (25 $\%$ EtOAc in $n$-hexane): mp 173-175 ${ }^{\circ} \mathrm{C}$ : IR (KBr) 1712. $1663,1602.1325 \mathrm{~cm}^{-1} ;{ }^{1} \mathrm{H} \mathrm{NMR}\left(\mathrm{CDCl}_{3}\right) \delta 8.41$ (dd. $J=1.5$ and $8.0 \mathrm{~Hz} . \mathrm{lH}) .7 .68-7.62(\mathrm{~m}, 2 \mathrm{H}), 7.52(\mathrm{t} . J=11.0 \mathrm{~Hz}$. lH), $2.58-2.49(\mathrm{~m}, 2 \mathrm{H}), 1.78(\mathrm{~s} .3 \mathrm{H}), 1.69-1.61(\mathrm{~m} .2 \mathrm{H}):{ }^{13} \mathrm{C}$ NMR $\left(\mathrm{CDCl}_{3}\right) \delta 209.1$. 184.9. 147.2, 135.0, 134.1, 129.5 . 129.2 129.0. 127.6. 40.1. 40.0. 39.9, 31.4: MS $m: z 35$ $\left(\mathrm{M}^{+}+1\right), 264.246,221$.

Compound 12e(Bis-Michael adduct): $\mathrm{mp} 132-134^{\circ} \mathrm{C}$ : IR (KBr) 1707. $1659 \mathrm{~cm}^{-1}$; ${ }^{1} \mathrm{H}$ NMR (200 MHZ: $\left.\mathrm{CDCl}_{3}\right) \delta$ 0.81 (t. $J=7.3 \mathrm{~Hz} .6 \mathrm{H}), 1.58-1.86(\mathrm{~m}, 4 \mathrm{H}) .1 .98$ (q. $J=7.3$ $\mathrm{Hz}, 4 \mathrm{H}), 2.51-2.60(\mathrm{~m}, 4 \mathrm{H}) .7 .49(\mathrm{t}, J=7.9 \mathrm{~Hz}, 2 \mathrm{H}), 7.59-$ $7.70(\mathrm{~m}, 4 \mathrm{H}), 8.4 \mathrm{l}($ d. $J=9.1 \mathrm{~Hz}, 2 \mathrm{H}) ;{ }^{13} \mathrm{C}$ NMR $(50 \mathrm{MHz}$ : $\left.\mathrm{CDCl}_{3}\right) \delta 9.1$. 37.4. 38.8. 40.1, 46.2, $127.7,129.0,129.2$. 134. 1, 136.0, 147.3, 185.0, 211.9: MS $m / 2363(\mathrm{M}+1), 316$. 278. 260 .

Compound 12f(Bis-Michael adduct): A solution of phenyl vinyl ketone (prepared from 3-dimethylaminopropiophenone) ( $290 \mathrm{mg}, 2.2 \mathrm{mumol}$ ). anthrone ( $194 \mathrm{mg}, 1.0 \mathrm{mmol}$ ) and sodium ethoxide ( $3 \mathrm{mg}, 0.04 \mathrm{mmol}$ ) in ethanol $(2.0 \mathrm{~mL}$ ) was refluxed for $3 \mathrm{~h}$. The residue was chromatographed over silica gel (2\% EtOAc in benzene) to give 10.10-bis-[(2benzoyl)ethyl]- $9(10)$-anthracenone $12 \mathrm{f}(227 \mathrm{mg} .50 \%)$ as a white solid.

TLC $R_{f} 0.47$ (25\% EtOAc in $n$-hexane); mp $180-184^{\circ} \mathrm{C}$ : IR (KBr) 1680, 1655. 1600, 1458. $1324 \mathrm{~cm}^{-1}:{ }^{1} \mathrm{H}$ NMR
$\left(\mathrm{CDCl}_{3}\right) \delta 8.47(\mathrm{~d} . J=7.7 \mathrm{~Hz} . \mathrm{lH}), 7.73-7.70(\mathrm{~m}, 2 \mathrm{H}) .7 .57-$ $7.4 \mathrm{l}(\mathrm{m}, 4 \mathrm{H}), 7.33-7.26(\mathrm{~m} .2 \mathrm{H}), 2.83-2.75$ (m. 2H). 2.272.19 (m. $2 \mathrm{H}):{ }^{13} \mathrm{C}$ NMR $\left(\mathrm{CDCl}_{3}\right) \delta 200.7$. 185.5. 147.3, 138.0, 136.1. 134.7, 134.2. 130.0, 129.4. 129.1, 127.7, 46.5, 40.9. 35.1: $\mathrm{MS} m z 446\left(\mathrm{M}^{+}-12\right), 362.337,326.305 .194$.

Compound 12g(Bis-Michael adduct): TLC $R_{f} 0.15$ (25 $\%$ EtOAc in $n$-hexane): $\mathrm{mp} 213-215^{\circ} \mathrm{C}$; IR (KBr) 2244 , 1662. $1458,1326 \mathrm{~cm}^{-1}:{ }^{1} \mathrm{H}$ NMR $\left(\mathrm{CDCl}_{3}\right) \delta 8.45$ (d. $J=9.6$ Hz. lH). $7.8 \mathrm{l}(\mathrm{t} . J=7.6 \mathrm{~Hz}, \mathrm{lH}) .7 .65-7.56(\mathrm{~m}, 2 \mathrm{H}), 2.70-$ $2.62(\mathrm{~m} .2 \mathrm{H}) .1 .65-1.56(\mathrm{~m}, 2 \mathrm{H}):{ }^{13} \mathrm{C} \mathrm{NMR}\left(\mathrm{CDCl}_{3}\right) \delta 183.6$, 143.7, 135.7. 134.4. 130.3. 128.9. 127.1, 119.9, 46.5. 41.8, 14.1; MS $m=248\left[\mathrm{M}^{-}-52\left(\mathrm{C}_{3} \mathrm{H}_{3} \mathrm{~N}\right)\right] .247 .207,179.152$.

Compound 12h(Bis-Michael adduct): TLC $R_{f} 0.45$ (25 $\%$ EtOAc in $n$-hexane): $m p 210-212^{\circ} \mathrm{C}$; IR (KBr) 1663 . 1600. 1447. 1304. $1152 \mathrm{~cm}^{-1},{ }^{1} \mathrm{H} \mathrm{NMR}\left(\mathrm{CDCl}_{3}\right) \delta 8.34$ (d. $J$ $=9.4 \mathrm{~Hz}, \mathrm{lH}) .7 .62-7.43(\mathrm{~m}, 7 \mathrm{H}), 7.29-7.25(\mathrm{~m} . \mathrm{lH}) .2 .64-$ $2.55(\mathrm{~m} .2 \mathrm{H}) .2 .27-2.17(\mathrm{~m}, 2 \mathrm{H}){ }^{13}{ }^{13} \mathrm{C} \mathrm{NMR}\left(\mathrm{CDCl}_{3}\right) \delta 183.6$, 144.0, 139.9, 136.5. 135.4. 133.8, 130.9. 129.9. 129.8, $129.4,126.7 .52 .9 .45 .4 .38 .8$.

Compound 12i(Mono-Michael adduct): TLC $R_{f} 0.45$ (25\% EtOAc in $n$-hexane); IR (KBr) 1734. 1665, 1601. 1314 $\mathrm{cm}^{-1}$ : ${ }^{1} \mathrm{H}$ NMR $\left(\mathrm{CDCl}_{3}\right) \delta 8.29-8.21(\mathrm{~m} .2 \mathrm{H}), 7.63-7.39(\mathrm{~m}$, $6 \mathrm{H}) .4 .28(\mathrm{~d}, J=3.3 \mathrm{~Hz} . \mathrm{lH}) .2 .70(\mathrm{~s}, 3 \mathrm{H}), 2.61-2.54(\mathrm{~m}$, lH). $2.43-2.3 \mathrm{l}(\mathrm{m} . \mathrm{lH}) .2 .06-1.94(\mathrm{~m} . \mathrm{lH}) .0 .56(\mathrm{~d} . J=6.9$ Hz. $3 \mathrm{H}):{ }^{13} \mathrm{C}$ NMR $\left(\mathrm{CDCl}_{3}\right) \delta$ 183.2. 174.6, 145.3, 143.3, $135.2,134.7,134.3$. 133.9. 130.4, 130.2. 128.9. 128.8, $128.6,53.3 .48 .5,41.8 .40 .1,17.0$.

Compound $12 \mathrm{j}$ (Mono-Michael adduct): TLC $R_{f} 0.29$ ( $10 \%$ EtOAc in benzene); mp 104-107 ${ }^{\circ} \mathrm{C}$. IR (KBr) 1710 . 1665. 1599. 1311. $109 \mathrm{I} \mathrm{cm}^{-1}$. ${ }^{1} \mathrm{H} \mathrm{NMR}\left(\mathrm{CDCl}_{3}\right) \delta 8.32-8.26$ (m. $2 \mathrm{H}), 7.69-7.44$ (m. $6 \mathrm{H}), 4.56($ d. $J=3.3 \mathrm{~Hz}, \mathrm{lH}) .4 .17-$ $4.10(\mathrm{~m}, 2 \mathrm{H}), 3.49$ (s. 3H). 1.97-1.82 (m, 5H): ${ }^{12} \mathrm{C}$ NMR $\left(\mathrm{CDCl}_{3}\right) \delta 207.8,186.4$. 142.4. 134.5, 134.1, 131.1. 130.3. $129.2,129.0 .128 .7,85.1 .59 .6 .46 .0,45.2,32.6 ;$ MS $m \geq 263$ $\left[\mathrm{M}^{-}-3 \mathrm{l}\left(\mathrm{OCH}_{3}\right)\right] .248,238.195 .165$.

Compound $12 \mathrm{k}$ (Mono-Michael adduct): TLC $R_{f} 0.24$ (10\% EtOAc in $n$-hexane); mp $96-99{ }^{\circ} \mathrm{C}$; IR (KBr) 1735 , 1661. $1599.1315 \mathrm{~cm}^{-1} ;{ }^{1} \mathrm{H}$ NMR $\left(\mathrm{CDCl}_{2}\right) \delta 8.25$ (d. $J=8.0$ Hz. $2 \mathrm{H}), 7.64-7.43(\mathrm{~m}, 6 \mathrm{H}), 4.26(\mathrm{~d}, J=5.6 \mathrm{~Hz}, \mathrm{lH}) .2 .55-$ $2.46(\mathrm{~m} . \mathrm{lH}), 2.15-1.63(\mathrm{~m}, 5 \mathrm{H}) .1 .47-1.42(\mathrm{~m} . \mathrm{lH}):{ }^{13} \mathrm{C}$ NMR $\left(\mathrm{CDCl}_{3}\right) \delta 218.2 .186 .6 .144 .5 .143 .9,134.7,134.6$. 134.2, 134.0. 130.3. 130.0. 129.3. 129.2, 129.1, 49.7. 48.4, 44.4. 39.9. 27.9: $\mathrm{MS} m z 196\left[\mathrm{M}^{-}-80\left(\mathrm{C}_{5} \mathrm{H}_{4} \mathrm{O}\right)\right], 166,139$, 115.82 .

Compound 121(Mono-Michael adduct): TLC $R_{f} 0.18$ (10\% EtOAc in $n$-hexane); mp 128-130 ${ }^{\circ} \mathrm{C}$; IR (KBr) 1702 , 1663. $1600.1464 .1315 \mathrm{~cm}^{-1},{ }^{1} \mathrm{H} \mathrm{NMR}\left(\mathrm{CDCl}_{3}\right) \delta 8.25$ (d. $J$ $=7.5 \mathrm{~Hz} .2 \mathrm{H}), 7.61 .7 .38(\mathrm{~m}, 6 \mathrm{H}) .4 .20(\mathrm{~d} . J=3.6 \mathrm{~Hz} . \mathrm{lH})$. $2.31-2.14(\mathrm{~m}, 3 \mathrm{H}), 1.98-1.82(\mathrm{~m}, 3 \mathrm{H}), 1.70-1.62(\mathrm{~m}, \mathrm{lH})$, $1.48-1.34(\mathrm{~m}, \mathrm{lH}) .0 .98$ (dt. $J=3.3$ and $12.2 \mathrm{~Hz} .1 \mathrm{H}$ ): ${ }^{13} \mathrm{C}$ NMR $\left(\mathrm{CDCl}_{3}\right) \delta 212.1$. 186.7. 143.9. 143.4, 135.0, 134.1. $130.3,130.2$. 129.2. 129.1. 128.9. 128.8, 128.7, 50.2. 50.0, 46.9. 42.5. 29.2, 26.4; MS $m=291\left(\mathrm{M}^{-}+1\right), 232.202 .195$. 165.

Acknowledgment. We gratefully acknowledged the financial support from the Regional Research Center Program of 
MOST and KOSEF. This work was partly supported by grant No. R01-2003-000-10187-0 from the Basic Research Progran of the KOSEF.

\section{References}

1. (a) Beak. P.: Mills. S. G. J. Org (them. 1985, 50, 1216. (b) Kanamaru, N.: Nagakura, S. J. Ant Chem. Soc. 1968.90. 6905.2 .

2. (a) Meek, J. S.: Etans. W. B.: Godefroi, V: Benson, W. R: Wilcox. M. F.: Clark. W. G.: Tiedeman. T. J. Org. Chem. 1961. 26. 4281. (b) Gomez-Bengona. E.: Cuerva. J. M.: Mateco. C.: Echavarren. A. M. J. Am. (Them. Soc. 1996. 118.8553.

3. (a) Brlson. H. A. J. Org Chem. 1942, 7, 2457. (b) Brlson. H. A: Riener. T. W. J. Am. Chem. Soc. 1942, 64. 2850. (c) Money. T: Raphael, R. A.: Scott. A. I: Young. D. W. J. Chem. Soc. 1961. 3958 .

4. (a) Meek. J. S.: Monroe. P. A.: Bouboulis. C. J. J. Org. Chem. 1963. 28. 2572. (b) Meek. J. S.: Dann. J. R.: Poon. B. T. J. Am. Chem. Soc. 1956, 78. 5413 . (c) Meek, J. S.: Poon. B. T.: Cristol, S. I. J. Am. Chem. Soc. 1952.74, 761 .

5. The energies were calculated by the AM-l calculation after geometry optimization.

6. Cohen. D.: Miller. I. T.: Richards. K. E. J. Chem. Soc. (C) 1968. 793. 7.

7. Kanpp, S.: Omaf. R. M.: Rodriques. K. J. Am. Chem. Soc. 1983.
105.5494

8. (a) Koerner. M.: Rickbort1. B. J. Org Chem 1991. 56. 1373. (b) Koerner, M.: Rickborn, B. J. Org. Chem. 1990, 55. 2662. (c) Koerner, M; Rickborn, B. J. Ong Chent 1989, 5t, 9.

9. For O-alhyalation, see: (a) Willner, I:- Halpern. M. Swhthesis 1979. 177. (b) Pirkle. W. H.: Finn. T. M. J. Org. Chem. 1983. 48. 2779. (c) Barnett. W. E.: Needham. L. L. J. Org. Chem. 1971. 36.4134 For C-alkylation. see: (d) Dimmel. D. R.: Shepard. D. J. Ong Chent 1982. 77. 22. (e) Majumdar. K. C. Chattopadhyav. S. K Khan. A. T. Stmithesis 1988, 552. (f) Majumdar, K. C.; Khan. A. T.: Chattopadiyay. S. K. J. Chent. Soc. Chent Conmm 1989. 655 .

10. The rough relative reactivity of dienophile is as follows: 1 for cyclohexene. $10^{3}$ for cyclopentene. $10^{4}$ for norbomene. $10^{6}$ for methyl acrylate. $10^{\circ}$ for dimethyl fumarate. maleonitrile and fumaronitrile, and $10^{10}$ for maleic anhydride. See ref. $8 \mathrm{~b}$.

11. Baik. W: Yoon, C. H.; Lee. K. C.: Lee, H. J: Koo. S.; Yoon, B.; Kim. H. J. Chem Res. (S) 1998. 358

12. Bergmann. E. D.: Ginsburg. D.: Pappo. R. Organic Reactions 1959. 10.179.

13. Truce. W. E.; Wellisch. E. J. Am. Chem. Soc. 1952. 7t. 2881 .

14. Inukai. T:, Kojima T. J. Org Chent 1967, 32.872

15. (a) Evan1s. D. A.: Golob. A. M. J. Am. Chem. Soc. 1975. 97. 4765. (b) Papies. O.: Grimme. W. Tethohedron Lett 1980. 21. 2799. (c) Zoeckler. M. T.: Carpenter. B. K. J. Am. Chem. Soc. 1981. 103. 7661 . 